\title{
A Methodology for the Identification and Characterization of Low-Temperature Waste Heat Sources and Sinks in Industrial Processes: Application in the Italian Dairy Sector
}

\author{
Lorena Giordano * and Miriam Benedetti $\mathbb{D}$
}

check for

updates

Citation: Giordano, L.; Benedetti, M. A Methodology for the Identification and Characterization of

Low-Temperature Waste Heat

Sources and Sinks in Industrial

Processes: Application in the Italian

Dairy Sector. Energies 2022, 15, 155.

https://doi.org/10.3390/en15010155

Academic Editors: Chiara Martini and Claudia Toro

Received: 15 November 2021

Accepted: 20 December 2021

Published: 27 December 2021

Publisher's Note: MDPI stays neutral with regard to jurisdictional claims in published maps and institutional affiliations.

Copyright: (C) 2021 by the authors. Licensee MDPI, Basel, Switzerland. This article is an open access article distributed under the terms and conditions of the Creative Commons Attribution (CC BY) license (https:// creativecommons.org/licenses/by/ $4.0 /)$.
Energy and Sustainable Economic Development (ENEA), Italian National Agency for New Technologies, 00123 Rome, Italy; miriam.benedetti@enea.it

* Correspondence: lorena.giordano@enea.it; Tel.: +39-063-04-834-301

\begin{abstract}
Waste heat recovery is considered as one of the most promising options to improve the efficiency and sustainability of industrial processes. Even though industrial waste heat is abundantly available and its utilization is not a new concept, the implementation rate of waste-heat recovery interventions in industrial facilities is still low, due to several real or perceived barriers. Foremost challenges are represented by technical, economic, financial and regulatory factors. An additional prominent barrier lies in the lack or incompleteness of information concerning the material and energy flows within the factories, and the types and characteristics of waste heat sources and possible sinks for their internal or external reuse. With the aim to overcome some of the information barriers and increase the willingness of companies to approach waste heat recovery and reuse, a methodology to map waste heat sources and sinks in industrial processes is proposed in this study. The approach here presented combines information from the most relevant publications on the subject and data gathered from the analysis of energy audits carried out by large and energy-intensive enterprises. In order to demonstrate its feasibility, the methodology was applied to the Italian dairy sector, because of its large energy consumption and its enormous potential for the utilization of low-temperature waste heat sources.
\end{abstract}

Keywords: energy efficiency; waste heat recovery; waste heat survey; dairy industry

\section{Introduction}

Energy efficiency represents one of the key principles of the European energy policies, being considered as the most affordable and effective way to reduce greenhouse gases (GHG) emissions and energy dependency, increase the security of supply and strengthen the competitiveness and environmental sustainability of EU countries.

As part of the Clean Energy for all Europeans package [1], the revised Energy Efficiency Directive (EED) [2] set a new binding target of at least 32.5\% energy efficiency by 2030, that would lead to a reduction in GHG emissions of about $45 \%$. With the adoption of the European Green Deal in December 2019 [3], the European Commission raised the level of climate ambition, setting a new 2030 target of reducing GHG emissions by at least $55 \%$ (compared to 1990). To reach this goal, in July 2021, the European Commission has proposed a new directive on energy efficiency [4], raising the energy efficiency targets by at least $36-37 \%$ and $39-41 \%$ for primary and final energy consumption, respectively.

Despite a reduction of energy consumption driven by energy efficiency measures in the last years, industry is still one of the large energy users in EU, accounting for around $26 \%$ of the final energy consumption [5] and 21\% of GHG emissions [6] in 2019. As highlighted in the Strategy for Energy System Integration [7] defined in the framework of the European Green Deal, space and process heating in industry is responsible for more than $60 \%$ of the energy demand. Even though waste heat integration and process efficiency optimization are widespread practices across the industrial sectors, a huge amount of the 
energy consumed by heating processes is still wasted in the form of heat. Thus, the recovery of such waste heat can have a significant impact in supporting the reduction of energy demand and the decarbonization of industrial processes.

In view of this, the Strategy for Energy System Integration [7] promoted the transition to a "more circular" energy system, where unavoidable waste streams are reused for energy purposes and synergies among enterprises are exploited.

Despite its technical and economic benefits, waste heat recovery still remains unexplored, due to the existence of several technical and non-technical barriers. Major technical barriers include low heat transfer rates, temporal, spatial and quality mismatch between sources and sinks of waste heat, process-specific constraints and inaccessibility. Nontechnical barriers are represented by long payback periods due to high capital costs, the lack of economy of scale and proper subsidy policies. A further challenge is represented by informational barriers, namely the little confidence in waste heat recovery technologies and the lack or incompleteness of information regarding the material and energy flows within the industrial facilities, the origin, quality and quantity of waste heat sources and possible internal or external waste heat acceptors [8].

Challenges become even greater when considering the recovery from low (from $120^{\circ} \mathrm{C}$ to $\left.230{ }^{\circ} \mathrm{C}\right)$ and very-low $\left(<120^{\circ} \mathrm{C}\right)$ grade heat [9], which actually accounts for the greatest share of the overall theoretical (physical) waste heat production in EU industry (920 TWh) [10]. This is not only due to the low energy level, but also to the lack of maturity of certain suitable waste heat recovery technologies and the relatively limited knowledge on the subject compared to other energy efficiency measures.

Recently, a certain number of studies explored challenges and opportunities for lowtemperature waste heat recovery in many respects. A research branch reviewed the most suitable technologies for capturing waste heat, depending on temperature level, type of industrial process responsible for the production of excess heat and type of waste heat utilization (direct use or heat conversion) [11-13]. In addition to the direct use of waste heat via heat-exchangers, attention was paid to heat conversion technologies for heat-upgrade (absorption, compression and chemical heat pumps) and electricity production (ORC, Kalina cycles, thermoelectric generators) [13-17]. A recent study revised the potential of using nanofluids to enhance the efficiency of heat transfer in heat-to-heat and heat-to-power technologies [18].

The technical and economic feasibility of recovering low-temperature waste heat was also investigated via experimental analyses and simulations models. Case studies mainly concerned the recovery of waste heat generated in iron and steel [19-22], ceramic [23-26], paper and pulp [27,28], textile [29-33] and food sectors [34-43].

A few studies focused on the analysis of potential industrial sources of low-grade waste heat. In this regard, waste heat sources were classified according to the temperature level and type of industrial sector in $[13,44,45]$. Data on temperature and mass flow rate of waste heat available per unit of mass of product were provided only for textile and paper sectors [46] and food industry, focusing on dairy, meat, canned fruit and vegetable processing facilities $[47,48]$. As regards to dairy sector, studies in $[49,50]$ identified the potential sinks of waste heat, in the context of a wider investigation aimed at examining retrofit options for the energy efficiency enhancement of dairy processes.

The assessment of waste heat sources and the possible waste heat acceptors was also addressed in some recent works dealing with the development of tools for the simulation and optimization of waste heat recovery projects. In this regard, Simeone et al. [8] and Wooley et al. [51] built a decision support tool to evaluate the compatibility of waste heat sources and sinks, along with economic and environmental benefits arising from the integration of available heat exchanger technologies to recover waste heat within a manufacturing facility. Notably, the framework for the energy recovery assessment provides for a preliminary survey of waste heat sources and sinks, based on direct measurements via invasive or non-invasive devices. The European project Greenfoods [52,53] dealt with the definition of an energy audit and management tool for food and beverage industries, 
where waste heat sources are identified and preliminary quantified by knowing the energy inputs (natural gas, coal, electricity, etc.) and setting up mass and energy balances of manufacturing processes. The CE-HEAT project [54] implemented an on-line toolbox to perform a pre-feasibility analysis of different waste heat recovery options, assuming as input data the characteristics of waste heat sources in terms of type of emission, temperature and thermal power.

However, all these works [8,51-54] did not focus on the identification of waste heat sources released by the production processes, being regarded as input data or unknown data that need to be directly measured or indirectly evaluated by solving complex energy balances.

The literature review highlighted that there is a lack of comprehensive methodologies to systematically analyze industrial processes and identify the origin and the key characteristics of low-temperature waste heat sources and sinks. Furthermore, no methodology has attempted so far to identify waste heat sources and to relate them with potential heat sinks by using literature data for the preliminary assessment and large datasets collected through the analysis of energy audits for model refinement and validation.

This could represent a relevant leap forward an increased knowledge of waste heat recovery potentials and processes, thus facilitating the first approach of companies to this topic and reducing the amount of input data required to perform the feasibility analyses.

With the aim to fill this research gap, the current study presents a methodology for the identification and characterization of the whole set of waste heat streams within a production process and the potential waste heat acceptors, which can be effectively reproduced and applied to every industrial sector. The methodology will support stakeholders, such as academics and energy consultants, in accomplishing the assessment of waste heat sources, which represent the necessary preliminary step in evaluating the technical and the economic feasible waste heat potential within industrial processes.

Specifically, the methodology provides for the definition of a typical production process, the selection of process phases generating low-grade waste heat sources, the identification and thermodynamic characterization of waste heat sources at phase-level and, finally, the definition of possible sinks for waste heat reuse. This step-by-step approach is based on data from literature review and its validation via comparison with the information retrieved from the analysis of energy audits. Such information is periodically gathered by ENEA, the Italian National Agency for New Technologies, Energy and Sustainable Economic Development, in fulfilment of Italian Legislative Decree 102/2014 [55], which established mandatory energy audits for large and energy intensive companies every four years.

In order to assess its feasibility, the methodology was applied to some of the most common manufacturing processes of the Italian dairy industry, where low-grade waste heat is characterized by a huge potential, being generated from several process stages (pre-heating, pasteurization, sterilization, cooling, clean-in-place, etc.), in the form of steam condensate, hot water, cooling water and intermediate-product streams.

This work lies in the framework of a wider research project, funded by the Ministry of Economic Development through a three-year research plan named "Ricerca di Sistema Elettrico" ("Electric System Research"). The project aims to support industrial companies in the implementation of low-temperature waste heat recovery projects. Specifically, its main outcome will be an application software to identify industrial waste heat recovery opportunities and to select the most promising options, based on the evaluation and comparison of their energy, economic and environmental performances. Thus, the methodology proposed in this study will permit the development of a specific module of the software tool, containing data for a complete survey of waste heat sources and sinks related to three Italian industrial sectors (dairy, baked products and textile). 


\section{Methodology for the Identification and Characterization of Low-Temperature Waste Heat Sources within Industrial Processes}

Industrial processes involve a set of unit operations to convert raw materials into finished parts or products. Each unit operation is a basic step, where a physical or a chemical transformation is performed, depending on the characteristics of inlet and outlet mass and energy flows. Waste heat energy streams are represented by outlet flows, in the form of hot air, hot exhaust gases, and hot liquids, that are released into the environment at temperatures high enough above the ambient temperature to permit the recovery of some fraction of their thermal energy for useful purposes.

As well-known, the production process of a given product can change significantly from one industry to another. This is because manufacturing plants have unique characteristics, in terms of size, structure and operating procedures, that affect the pattern of mass and energy flows.

A common approach to overcome this issue is to model a typical production process, allowing to generically analyze inlet and outlet mass and energy flows and identify waste heat sources within the process itself [56]. Depending on temperature level of waste heat sources and sinks, possible combinations and waste heat recovery technologies can be preliminary identified.

Using such approach, a step-by-step methodology was defined to accomplish a complete survey of waste heat sources and sinks within industrial processes. On the basis of data collected from technical manuals, reports and research papers, the methodology allows for the definition of a typical production process, the selection of process phases generating low-grade waste heat sources, the identification and thermodynamic characterization of waste heat sources at phase-level and, finally, the definition of possible sinks for waste heat reuse. As a result, two preliminary schemes are obtained: a process scheme and a scheme of low-temperature waste heat sources. Using data arising from the analysis of energy audits, the information collected in these schemes is validated, enriched, contextualized and, finally, merged together to form a new comprehensive scheme.

Furthermore, an additional scheme concerning waste heat sinks is generated by combining literature data with data arising from waste heat recovery projects envisaged in the framework of energy audits. The two schemes can be overlapped in order to obtain a complete description of the process, the related waste heat generated and the possible ways to reuse it.

Specifically, the methodology adopted for the definition of a "typical" production process scheme includes four main steps:

(a) Review of the technical literature related to the industrial sectors

In this step, the reference documents on the best available techniques (BREF), technical reports and scientific articles are gathered and analyzed to acquire preliminary information on the main types of production processes operated within the industrial sector of interest. Based on the type and amount of information available, production processes to be further investigated are identified.

(b) Identification of process schemes from literature

With reference to production processes defined at point (a), process schemes, indicating the set of process phases required to turn raw materials into the final product, are identified from the literature review.

\section{(c) Comparison of process schemes from literature}

Process schemes from literature concerning the same product are compared to verify the existence of any differences in terms of sequence and operating conditions of production phases.

(d) Definition of a scheme of a "typical" production process 
Based on the analysis and comparison of the process schemes from literature, as indicated at points (b) and (c), a "typical" process scheme for each product is defined. The scheme indicates:

- $\quad$ the sequence of phases of a typical production unit, starting from the preparation of raw materials up to the manufacturing and finishing of the final product;

- the raw materials and the auxiliary services required (water, steam, compressed air, etc.);

- the phases generating low-grade waste heat.

After defining the "typical" process scheme of a certain product, a scheme of waste heat sources is obtained via a four-step procedure, as detailed below:

(e) Preliminary identification of waste heat sources

In the first step, phases within the "typical" process scheme generating low-grade waste heat (point (d)) are carefully analyzed. The aim is to carry out a preliminary survey of low-temperature waste heat sources, based on the analysis of the relative inlet and outlet material flows and energy vectors (natural gas, steam, hot water, air, etc.).

\section{(f) Comparison and verification based on literature data}

The potential waste heat sources identified at point (e) are compared with those indicated in literature studies, such as scientific articles focusing on waste heat recovery in industrial processes or technical manuals concerning the energy efficiency of industrial processes. The purpose is to validate the types of waste heat sources previously identified and to detect any additional low-grade heat loss not directly deducible from the analysis of the "typical" process scheme.

(g) Characterization of waste heat sources based on literature data

Using the information gathered from scientific articles and technical manuals concerning the efficiency of industrial processes, waste heat sources are characterized, depending on data availability, in terms of type of vector (exhaust gas, steam, condensate, etc.), temperature, pressure, mass flow rate and theoretical waste heat recoverable.

(h) Definition of a scheme of low-temperature waste heat sources

Integrating the data set characterizing the waste heat sources (temperature, pressure, flow rate, theoretical waste heat recoverable per unit of product, etc.), a preliminary scheme of low-temperature waste heat sources is defined. Depending on temperature level of waste heat sources, candidate energy sinks and waste heat recovery technologies are also preliminary identified on the basis of information gathered from the technical literature review.

Validation and Contextualization via Comparison with Data from Energy Audits and Identification of Possible Waste Heat Sinks

The energy audit is widely regarded as one of the most cost-effective instruments for analyzing energy flows and assessing energy consumption within enterprises or individual processes and exploring potential energy, cost and emission saving opportunities [57,58]. From a regulatory point of view, the energy audit is regulated by the Article 8 of EED [2], according to all large enterprises shall undertake an independent, cost-effective and highquality energy audit at least every four years or they may implement an energy or environmental management system, which includes an energy audit. In compliance with the EU regulatory framework, Article 8 has been transposed into the Italian legislation via the Legislative Decree N. 102 of 4 July 2014 [55], recently updated by the Legislative Decree n. 73/2020 [59]. According to article 8 of such Decree, the energy audit obligation applies to large (as defined in [60]) and energy intensive industries, intended as the ones with large energy consumptions (electricity consumption more than $1 \mathrm{GWh}$ /year) applying for a tax relief on part of the purchased energy. All the energy intensive enterprises are registered on the list of "Cassa per i servizi energetici ed ambientali" ("Fund for Energy 
and Environmental Services - CSEA"). The Italian energy audit program, including data gathering and sector analysis, is managed by ENEA, which has received on 31 December $2019,11,172$ energy audits of production sites related to 6434 companies.

In the framework of the proposed methodology, the analysis of energy audits carried out by enterprises in the industrial sectors of interest is aimed at retrieving information about product processing, types and characteristics of waste heat recovery sources at different process stages and case studies regarding the implementation of technologies or solutions for the reuse of waste heat.

The purpose of such investigation is twofold:

- $\quad$ validating, enriching and contextualizing at national level the schemes of product manufacturing process and waste heat sources generated as a byproduct;

- $\quad$ identifying possible waste heat acceptors other than those defined in technical literature.

Figure 1 summarizes the main phases of the methodology developed in this study to define the schemes of product manufacturing process and low-temperature waste heat sources.

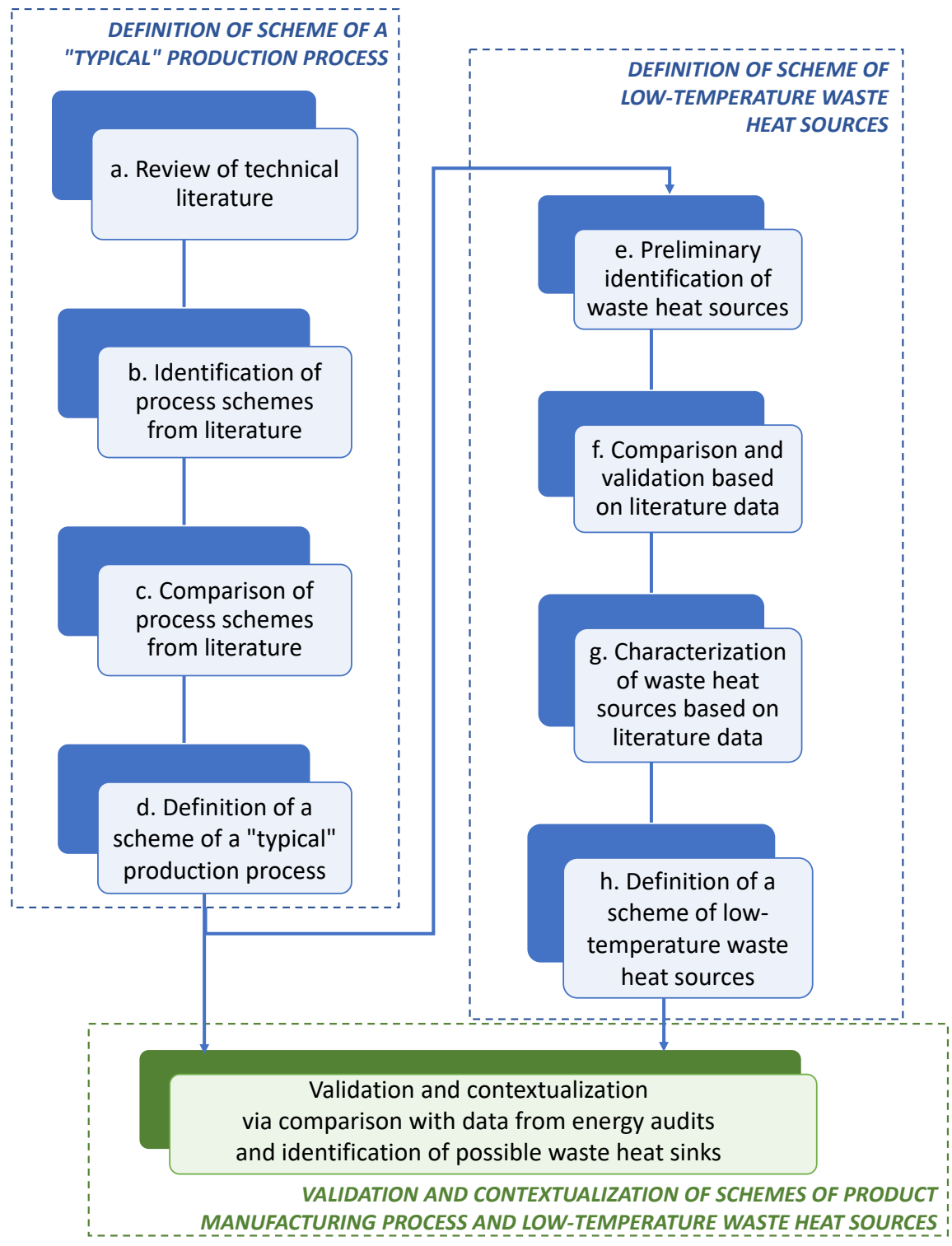

Figure 1. Methodology for the identification and characterization of the schemes of product manufacturing process (steps $(\mathbf{a}-\mathbf{d}))$ and low-temperature waste heat sources within the industrial processes (steps $(\mathbf{e}-\mathbf{h}))$. 


\section{Application of the Methodology to the Case of Dairy Sector}

With the aim of demonstrating its feasibility, the methodology was applied to the case of dairy sector, taking as a reference the process of pasteurized milk production. The literature review allowed to identify documents containing information and process schemes regarding the pasteurized milk production. Attention was focused on the reference document on the best available techniques (BREF) for food, beverage and milk industry [61] and the study by Ramirez et al. [62], where two different process schemes were identified: the first one refers to the production process of pasteurized milk, while the second scheme outlines the process phases of the main dairy products, such as milk, powdered and condensed milk, yoghurt, butter and cheese. By analyzing and comparing these schemes, the set of stages involved in the pasteurized milk production and the temperature levels of each phase were defined. Reworking the information found in the literature, the scheme of a "typical" process for pasteurized milk production was defined. As shown in Figure 2, the new scheme:

- $\quad$ outlines the sequence of stages to convert raw milk into pasteurized milk;

- preliminarily identifies the main process phases responsible for low-temperature waste heat generation (indicated in black color in Figure 2), which include the phases of pasteurization and cooling of the pasteurized milk.

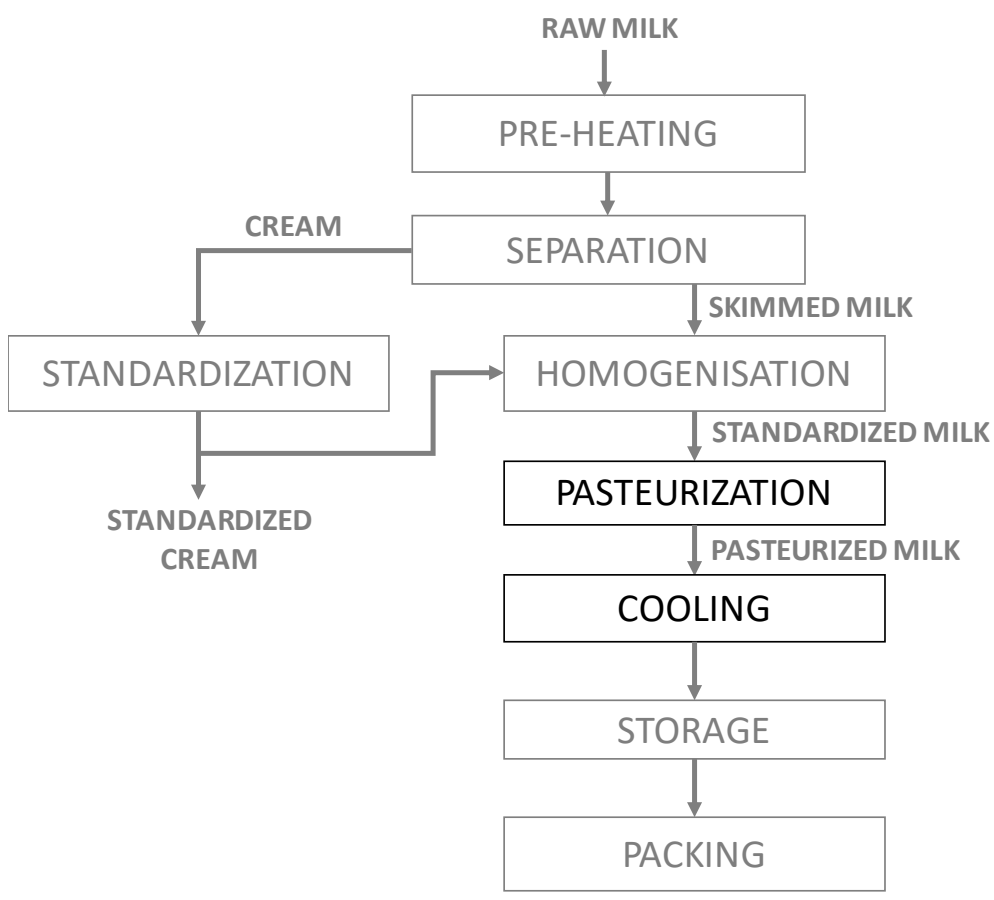

Figure 2. Scheme of a "typical" process for pasteurized milk production (from authors' elaboration).

After defining the typical flow diagram for pasteurized milk processing, a further investigation was carried out to characterize more comprehensively the process phases with low-temperature waste heat generation (pasteurization and cooling) and identify the corresponding waste heat streams.

Based on the analysis of mass and energy flows involved and the information found in [48,61-64], four low-temperature waste heat sources (S) were identified within the pasteurization phase, including:

- S1: the condensate of steam required for process water heating;

- S2: the hot process water at the pasteurizer outlet;

- S3: the pasteurizer overflow;

- S4: the water (or steam) used for the cleaning and sanitizing of the pasteurizer. 
Information included in the technical literature allowed to define temperature ranges of all waste heat streams (S1-S4) [48,64]; data concerning the waste heat mass flow rate per unit of raw milk treated were found only for the pasteurizer overflow (S3) and the water (or steam) for the pasteurizer clean-up (S4) [48].

Regarding the cooling process of pasteurized milk, waste heat is released during the condensation process of the refrigerant fluid evolving within chillers for cooling water production (S5). The heat of condensation is normally removed via cooling water in a closed loop and then released into the air $[65,66]$.

Combining the data previously collected, a preliminary scheme of low-temperature waste heat sources was outlined (Figure 3). Such diagram not only identifies and locates sources of low-temperature waste heat related to pasteurized milk processing, but it also provides a preliminary characterization of waste heat streams in terms of temperature and specific flow rates, depending on the information available in the literature.

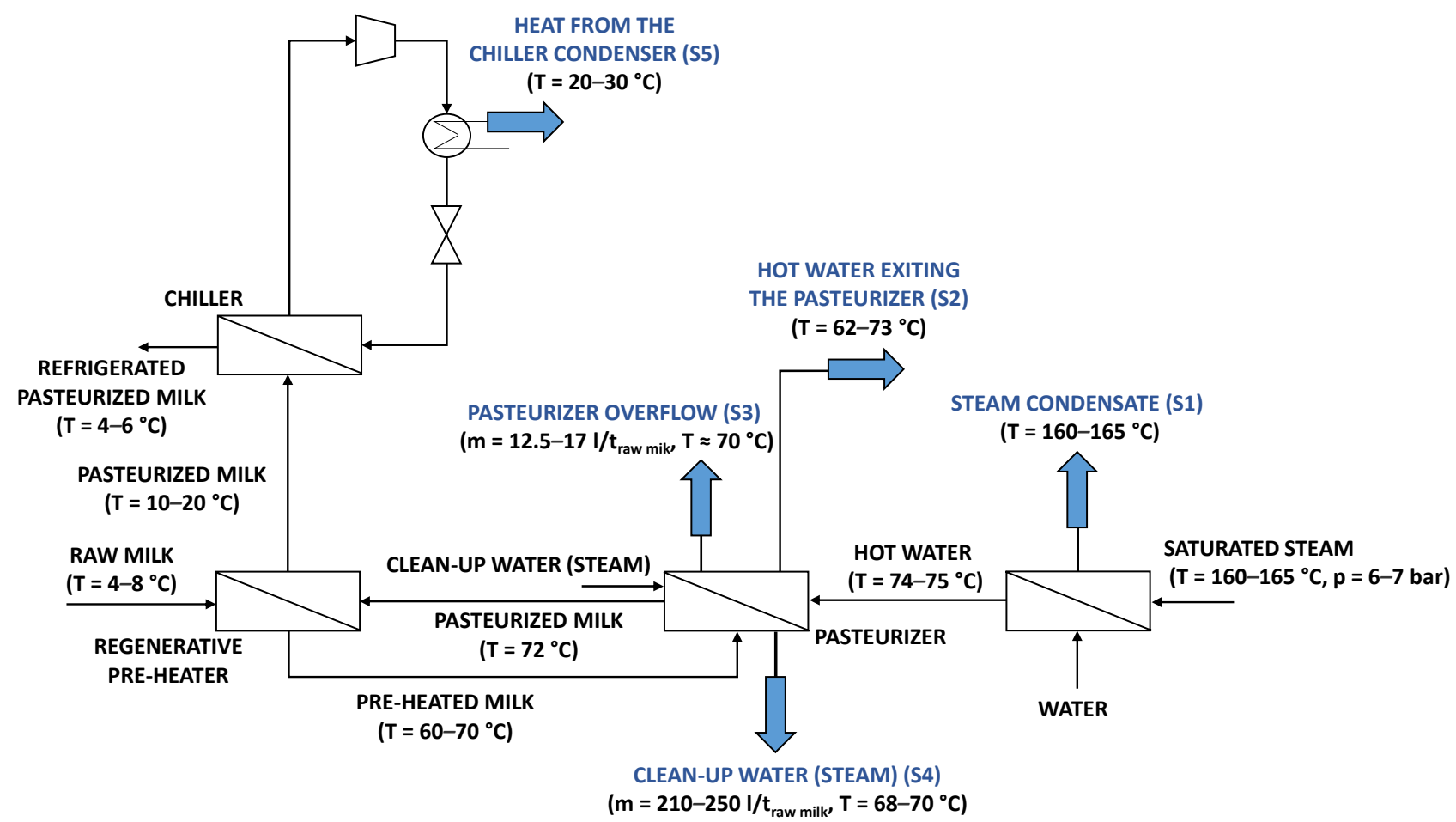

Figure 3. Scheme of low-temperature waste heat sources in pasteurized milk processing (from authors' elaboration).

\subsection{Analysis of the Energy Audits of the Italian Dairy Sector}

With the aim to validate, improve and contextualize the scheme of pasteurized milk production process and the corresponding scheme of low-temperature waste heat sources to the Italian dairy industry, energy audits carried out by large and energy-intensive enterprises in the year 2019, in compliance with the Legislative Decree N. 102 of 4 July 2014 [55], were examined. The paragraph outlines the main findings of this analysis, with a focus on waste heat sources identified within the manufacturing processes of dairy products and the waste heat recovery interventions envisaged by enterprises to improve their energy efficiency. It is important to emphasize that such information is rarely clearly stated in the energy audits, and the lexicon used by the enterprises is neither standardized nor always univocal. Therefore, the results presented in this paper were obtained by carefully analyzing and elaborating data retrieved from energy audits, which were then aggregated and presented in anonymous form. 


\subsubsection{Overview of the Italian Dairy Sector}

According to the ATECO classification, the dairy sector consists of two main subsectors [67]: "10.51.10—Hygienic treatment of milk" and "10.51.20—Production of milk derivatives". The first sub-sector includes companies whose main activity is the production of fresh, pasteurized, sterilized, homogenized or ultra-high temperature (UHT) milk. The second sub-sector comprises companies involved in the production of milk-based beverages, cream made with fresh, pasteurized, sterilized, homogenized liquid milk, powdered or concentrated milk, butter, yoghurt, cheese, curd, whey, lactose and lactic ferments.

The study focused on large and energy-intensive businesses, which are obliged to undertake an energy audit in compliance with the Italian Legislative Decree 102/2014. Specifically, data provided by 79 dairy enterprises were deeply analyzed. Over $70 \%$ of companies in this sample (57) belong to the sub-sector 10.51.20, while the remainder to the sub-sector $10.51 .10(22)$.

The Italian dairy industry is not a uniform sector, since the production capacity can vary significantly among enterprises. In this regard, Table 1 shows the diversification of the production sites investigated in terms of annual production, varying the unit of measure adopted (tons, kilograms, litres or number of pieces). As an example, the production capacity expressed in $t /$ year, which represents the most used unit of measure $(60 \%$ of the overall sample), ranges from $450 \mathrm{t} /$ year to approximately 400,000 t/year. A comparable dispersion is observed for the statistical distribution of annual productions in $\mathrm{kg} /$ year.

Table 1. Statistical distribution functions of the annual production of dairy enterprises investigated varying the unit of measure.

\begin{tabular}{|c|c|c|c|c|}
\hline & \multicolumn{4}{|c|}{ Unit of Measure of the Annual Production } \\
\hline & t/Year & $\left(\times 10^{3}\right) \mathrm{kg} /$ Year & $\left(\times 10^{3}\right)$ L/Year & Pieces/Year \\
\hline Sample size & 45 & 24 & 8 & 2 \\
\hline Min & 450.0 & 42.9 & 4807.0 & $54,393.0$ \\
\hline Lower quartile & $10,905.8$ & 3267.6 & $10,530.9$ & $57,459.8$ \\
\hline Median & $33,258.7$ & $12,531.0$ & $18,540.8$ & $60,526.5$ \\
\hline Mean & $60,358.2$ & $51,622.4$ & $20,127.4$ & $60,526.5$ \\
\hline Upper quartile & $83,254.7$ & $42,084.5$ & $27,483.1$ & $63,593.3$ \\
\hline Max & $399,319.0$ & $400,896.2$ & $41,943.6$ & $66,660.0$ \\
\hline Total & $2,716,118.3$ & $1,238,938.4$ & $161,019.3$ & $121,053.0$ \\
\hline
\end{tabular}

Milk processed in dairy industries is used to produce a wide variety of products: pasteurized milk, ultra-high-temperature milk, cream, butter, soft and hard cheese, yoghurt, ricotta, etc. Despite the differences in terms of production capacity and types of products, process steps involved in converting raw materials into finished products are quite similar. In this regard, Table 2 describes the sequence of unit operations required to produce some dairy products, defined on the basis of knowledge gathered from the analysis of energy audits. It is worth mentioning that the sequence of process stages for most of the products investigated has been elaborated by the authors of this paper combining all types of information available in the energy audits, including process schemes and data extrapolated by the descriptions of products manufacturing. 
Table 2. Unit operations involved in manufacturing of some dairy products according to the analysis of energy audits of dairy enterprises.

\begin{tabular}{|c|c|c|c|c|c|}
\hline Unit Operations & $\begin{array}{c}\text { Butter } \\
(2 *)\end{array}$ & $\begin{array}{c}\text { Cream } \\
(3 *)\end{array}$ & $\begin{array}{l}\text { Hard Cheese } \\
\qquad(3 *)\end{array}$ & $\begin{array}{l}\text { Pasteurized Milk } \\
(2 *)\end{array}$ & $\begin{array}{l}\text { Yoghurt } \\
\qquad\left(3^{*}\right)\end{array}$ \\
\hline plant sterilization & & $x$ & & $x$ & \\
\hline raw milk receiving & & & $X$ & $X$ & $X$ \\
\hline milk powder addition & & & & & $X$ \\
\hline filtration & & & $x$ & $x$ & \\
\hline cooling and storage & & & $x$ & $x$ & \\
\hline pre-heating & & & $x$ & $x$ & \\
\hline cream separation/skimming & & & $X$ & $x$ & $X * * *$ \\
\hline cream aging & & $X$ & & & \\
\hline bactofugation & & & $x$ & & \\
\hline homogeneization/ 1st homogenization & & & & $x$ & $X^{* * *}$ \\
\hline standardization & & & & $x$ & \\
\hline cream receiving and storage & $X$ & & & & \\
\hline heating and skimming & $x$ & & & & \\
\hline regeneration & $X$ & & & & \\
\hline \multicolumn{6}{|l|}{ cooling in storage tank } \\
\hline \multicolumn{6}{|l|}{ 1st pre-heating } \\
\hline \multicolumn{6}{|l|}{ 2nd pre-heating } \\
\hline $\begin{array}{c}\text { 1st pasteurization/ pasteurization } \\
\text { sterilization }\end{array}$ & $x$ & $x$ & $x$ & $x$ & $x$ \\
\hline thermization $* *$ & & & & & $x$ \\
\hline storage ${ }^{* *}$ & & & & & $x$ \\
\hline thermal treatment ** & & & & & $x$ \\
\hline concentration & & & & & $x$ \\
\hline cooling/1st cooling & $x$ & $x$ & $x$ & $x$ & $x$ \\
\hline whey starter and curd addition & & & $x$ & & \\
\hline cooking & & & $x$ & & \\
\hline coagulation & & & $X$ & & \\
\hline curd breaking and whey separation & & & $x$ & & \\
\hline shaping & & & $x$ & & \\
\hline moulds turning & & & $x$ & & \\
\hline resting (hot chamber) & & & $x$ & & \\
\hline transport to cold chamber & & & $X$ & & \\
\hline salting & & & $x$ & & \\
\hline drying and ripening & & & $X$ & & \\
\hline washing and surface treatment & & & $x$ & & \\
\hline 2nd pasteurization & $x$ & & & & \\
\hline steam separation (via degasser) & $x$ & & & & \\
\hline \multicolumn{6}{|l|}{ 2nd homogenization } \\
\hline starter culture inoculation and aging & $x$ & & & & $x$ \\
\hline 2nd cooling & & & & & $x$ \\
\hline churning & $x$ & & & & \\
\hline storage in agitated tank & & $X$ & & & \\
\hline fruits addition & & & & & $X$ \\
\hline handling and packing & $X$ & $X$ & $X$ & $x$ & $x$ \\
\hline storage & $X$ & & $X$ & & $x$ \\
\hline clean-in-place & $x$ & $x$ & $x$ & $x$ & $x$ \\
\hline
\end{tabular}

${ }^{*}$ number of energy audits analyzed, ${ }^{* *}$ only for processes without pasteurization; ${ }^{* * *}$ after pasteurization or thermal treatment.

As regard to the energy demand, natural gas is by far the most widely used fuel for the production of steam and hot water for several uses (i.e., product manufacturing, space heating, hot water production or the direct use in canteen stoves) and thus it is also the main responsible for the production of waste heat within dairy facilities. In this regard, Figure 4 shows the distribution function of the natural gas consumption of the entire sample of dairy enterprises. The yearly demand for natural gas is lower than or equal to $2100 \mathrm{kSm}^{3}$ 
for more than $80 \%$ of enterprises, while it ranges from 2100 to $4200 \mathrm{kSm}^{3}$ in only $10 \%$ of the sample.

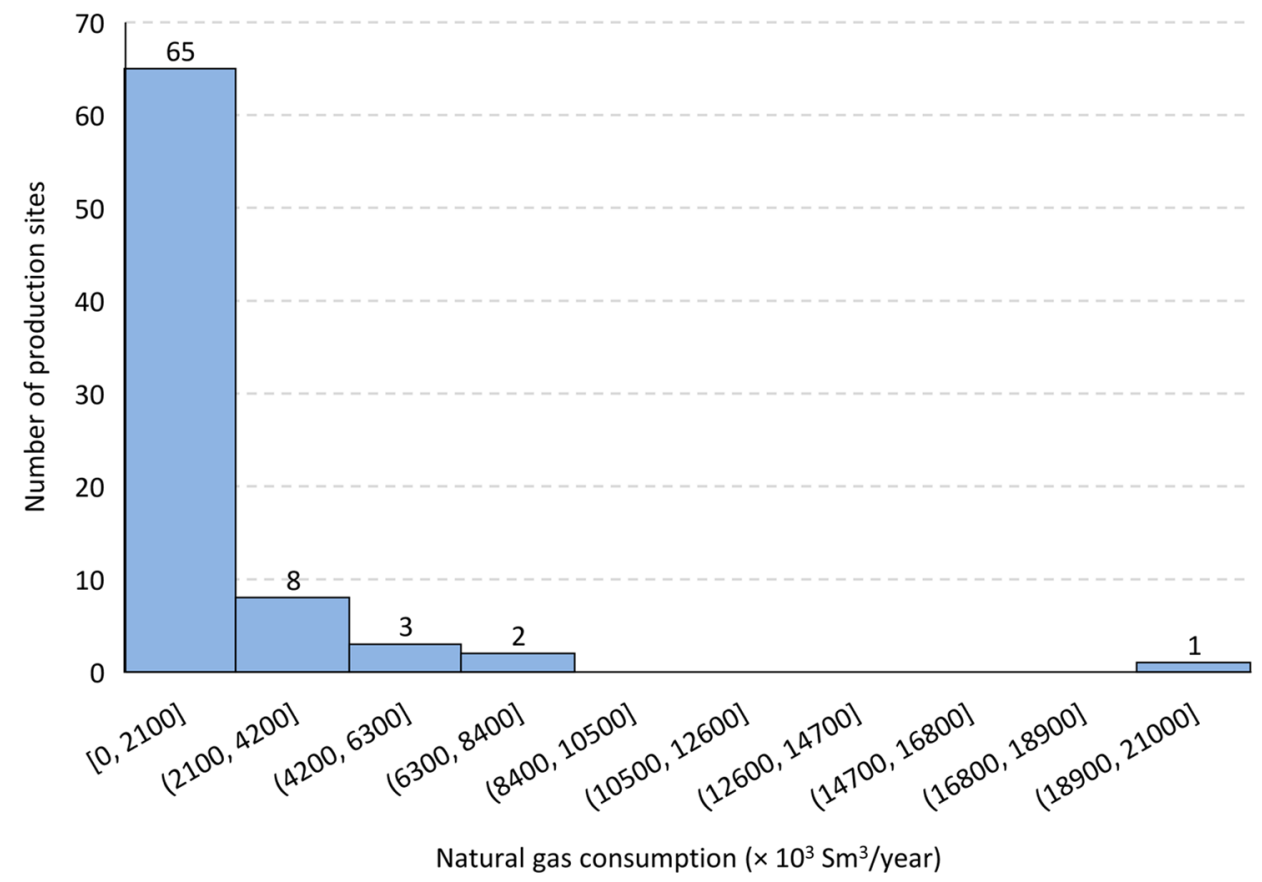

Figure 4. Distribution of yearly natural gas consumption of production sites investigated.

Based on annual data on natural gas demand and the production capacity of dairy companies investigated, the specific consumption of natural gas was also evaluated. In this regard, Figure 5 shows the trend of natural gas consumption per ton of product as a function of annual production capacity. To construct this graph, production capacities expressed in $\mathrm{kg} /$ year and in L/year were converted in $\mathrm{t} /$ year, while those in pieces/year were neglected. As shown in Figure 5, the specific consumption of natural gas decreases with the annual production according to a power law. A sharp decrease from about $300 \mathrm{Sm}^{3} / t$ to $25 \mathrm{Sm}^{3} / \mathrm{t}$ is observed for annual production values up to 50,000 t/year; conversely, when that threshold is exceeded, the specific consumption undergoes a less significant decrease, stating at a minimum value of approximately $3 \mathrm{Sm}^{3} / \mathrm{t}$.

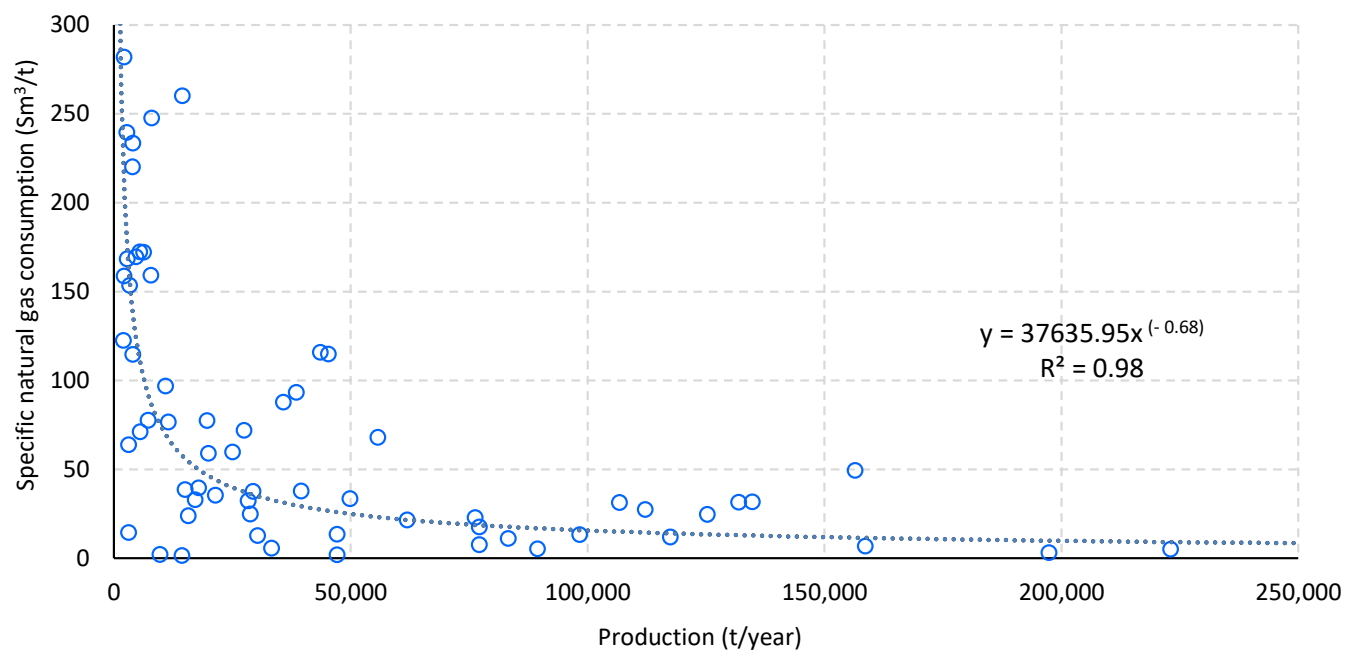

Figure 5. Trend of specific natural gas consumption as a function of the annual production capacity of dairy enterprises. 
It is noted that the specific consumption of natural gas is also affected by factors other than the annual production (i.e., the product demand) which were neglected in this study, since these analyses were performed for the only purpose of sample characterization.

\subsubsection{Waste Heat Recovery Interventions in the Italian Dairy Industry}

As part of the energy audits, the dairy enterprises under investigation identified 365 potential energy-saving measures, which can be grouped into 15 main categories: air conditioning systems, chillers, cogeneration/trigeneration systems, compressed air systems, electric engines, electrical systems, energy management systems, heat generators, hydraulic pumps, lighting systems, process water treatment systems, production lines, renewable energy technologies, waste heat recovery, wastewater treatment plants. More than 100 retrofit interventions concerned the efficiency improvement of the lighting systems (55) and the compressed air systems (52); other energy-efficiency measures in order of importance included the replacement or refurbishment of heat generators (32), the installation of renewable energy technologies (32) and the construction or retrofitting of cogeneration and trigeneration power plants (31). Regarding the recovery and valorization of waste heat, 30 interventions were identified. As depicted in Figure 6, over two thirds of waste heat recovery interventions involved the auxiliary systems, namely the compressed air systems, the cogeneration power plants and the chiller condensing systems. The remaining interventions concerned the production lines, including the waste heat recovery from the cooling process of the whey and the milk in the aging tanks, the waste heat recovery from the sterilization and process steam condensates from the evaporation and concentration of "scotta" and from the degasser of the UHT milk.

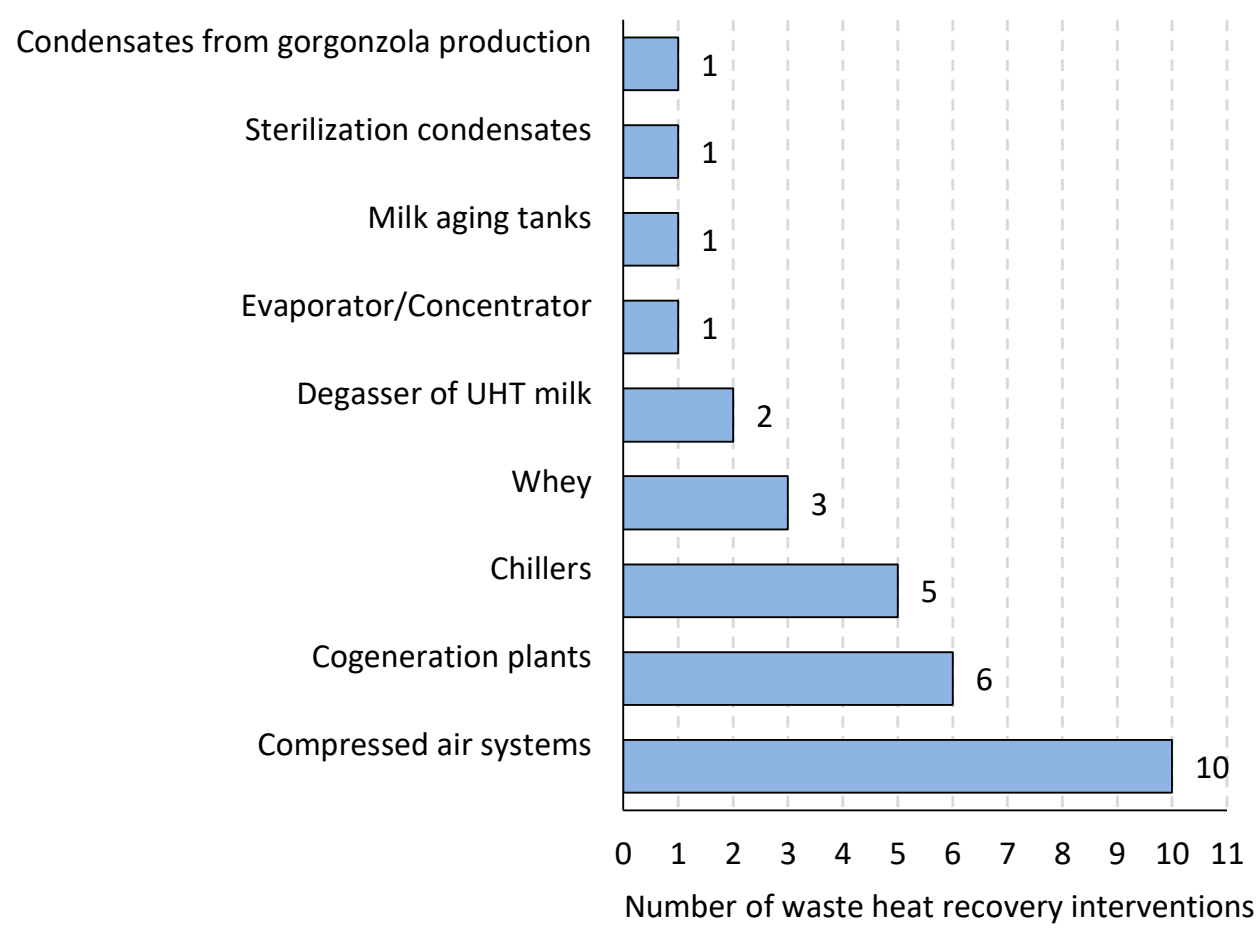

Figure 6. Number and type of waste heat recovery interventions.

Table 3 summarizes the waste heat "acceptors" according to the type of waste heat recovery intervention identified by the dairy enterprises investigated. In this regard, it is pointed out that the reuse of waste heat always occurred within the production facility itself. In the case of interventions related to the compressed air systems, the heat recovered was mainly intended for the production of domestic hot water or space heating; further uses included the heating of water of the air handling unit (AHU), the preheating of water at the boiler inlet and the preheating of cleaning water of process equipment (clean-in-place 
systems). The latter represented the main use of waste heat recovered from cogeneration plants, followed by the preheating of boiler make-up water, the production of chilled water and the whey heating during pasteurization. The heat recovered from the chiller condenser systems was mainly used for the preheating of water at the boiler inlet, water of clean-in-place systems and the boiler make-up water.

In the case of interventions related to the production lines, the waste heat was reused to support the product processing (i.e., for the preheating of skim milk, the reactivation of raw milk and the preheating of cleaning water) and to preheat water, air and fuel at the boiler inlet. A further type of intervention was the recovery of condensate from the sterilizers to support the production of process steam.

As outlined in Table 4, all waste heat recovery interventions envisaged by dairy enterprises were based on well-established technologies, notably heat exchangers, with or without a hot storage tank. In the case of waste heat recovery from auxiliary systems, heat exchangers were implemented in 17 cases out of 21; the remaining interventions provided for the use of canalizations or chimneys to collect the cooling air of compressors (intervention on the compressed air system) or the installation of an absorption refrigeration system (intervention on the cogeneration plant). In the case of waste recovery from the production lines, heat exchangers were virtually the only technology adopted, except in the case of steam condensate recovery from sterilizers.

\subsection{Validation of the Schematic Diagram of Waste Heat Sources via Comparison with Data from Energy Audits}

The analysis of energy audits allowed to validate and contextualize to the Italian dairy sector the process scheme for pasteurized milk manufacturing and the corresponding scheme of low-temperature waste heat sources.

In the case of pasteurized milk production, information was provided by the energy audits of two different production sites, including:

- the sequence of the production stages, starting from the receipt of raw materials up to the packing of the final product, including the maintenance of process equipment (sterilization and clean-in-place);

- the energy vectors used in the different production stages (steam, hot water, chilled water, etc.);

- the temperatures of raw materials, the intermediate and final products, depending on data availability.

The analysis of such information revealed that the sequence of process stages in pasteurized milk manufacturing is actually more complex than that reported in previous literature studies. Nevertheless, the limited amount of data available did not permit the further characterization of the waste heat sources in terms of mass flow rate or thermal power per unit mass of raw milk.

Combining the additional information gathered from the energy audits with the process scheme (Figure 2) and the scheme of low-temperature waste heat sources (Figure 3) obtained via the application of the proposed methodology (steps a-d and e-h, respectively), a new scheme was developed (Table 5). This provides for a more comprehensive and systematic description of the whole set of process stages involved in pasteurized milk production and the corresponding waste heat streams generated. As shown in Table 5, the scheme defines:

- the process stages involved in product manufacturing, with the identification of phases generating low-temperature waste heat;

- the energy vectors used in each stage, with the indication of temperature levels, depending on data availability;

- the low-temperature waste heat streams for each process stage, in order from the highest to the lowest temperature. 
Table 3. Uses of waste heat depending on the type of waste heat recovery intervention.

\begin{tabular}{|c|c|c|c|c|c|c|c|c|c|}
\hline $\begin{array}{ll}\text { Waste Heat Uses } \\
\text { Waste Heat Sources }\end{array}$ & $\begin{array}{l}\text { Compressed } \\
\text { Air Systems }\end{array}$ & $\begin{array}{l}\text { Cogeneration } \\
\text { Systems }\end{array}$ & Chillers & $\begin{array}{l}\text { Sterilization } \\
\text { Condensates }\end{array}$ & $\begin{array}{l}\text { Degasser of } \\
\text { UHT Milk }\end{array}$ & $\begin{array}{c}\text { Evaporator/ } \\
\text { Concentrator } \\
\text { of Scotta }\end{array}$ & $\begin{array}{l}\text { Aging } \\
\text { Tanks }\end{array}$ & $\begin{array}{c}\text { Condensates from } \\
\text { the Production of } \\
\text { Gorgonzola }\end{array}$ & Whey \\
\hline Milk preheating & - & - & - & - & 1 & - & - & - & 1 \\
\hline Reactivation of raw milk & - & - & - & - & - & - & - & - & 1 \\
\hline $\begin{array}{l}\text { Whey heating during } \\
\text { pasteurization }\end{array}$ & - & 1 & - & - & - & - & - & - & - \\
\hline Condensate recovery & - & - & - & 1 & - & - & - & 1 & - \\
\hline Preheating of water for clean-in-place & 1 & 3 & 2 & - & - & - & 1 & - & 1 \\
\hline $\begin{array}{c}\text { Domestic hot water production/Space } \\
\text { heating }\end{array}$ & 7 & - & - & - & - & - & - & - & - \\
\hline $\begin{array}{l}\text { Heating of water of air handling unit } \\
\text { (AHU) }\end{array}$ & 1 & - & - & - & - & - & - & - & - \\
\hline Preheating of water at the boiler inlet & 1 & - & 2 & - & 1 & - & - & - & - \\
\hline Air and fuel preheating & - & - & - & - & - & 1 & - & - & - \\
\hline Preheating of boiler make-up water & - & 1 & 1 & - & - & - & - & - & - \\
\hline $\begin{array}{c}\text { Production of chilled } \\
\text { water at } 0^{\circ} \mathrm{C}\end{array}$ & - & 1 & - & - & - & - & - & - & - \\
\hline
\end{tabular}

Table 4. Waste heat recovery technologies depending on the type of waste heat recovery intervention.

\begin{tabular}{|c|c|c|c|c|c|c|c|c|c|}
\hline $\begin{array}{l}\text { Waste Heat Sources } \\
\text { Waste Heat Recovery Technologies } \\
\end{array}$ & $\begin{array}{l}\text { Compressed } \\
\text { Air Systems }\end{array}$ & $\begin{array}{l}\text { Cogeneration } \\
\text { Systems }\end{array}$ & Chillers & $\begin{array}{l}\text { Sterilization } \\
\text { Condensates }\end{array}$ & $\begin{array}{l}\text { Degasser of } \\
\text { UHT Milk }\end{array}$ & $\begin{array}{c}\text { Evaporator/ } \\
\text { Concentrator } \\
\text { of Scotta } \\
\end{array}$ & $\begin{array}{l}\text { Aging } \\
\text { Tanks }\end{array}$ & $\begin{array}{c}\text { Condensates from } \\
\text { the Production of } \\
\text { Gorgonzola }\end{array}$ & Whey \\
\hline Heat exchanger & 6 & 4 & 5 & - & 2 & 1 & 1 & 1 & 2 \\
\hline Air canalizations & 1 & - & - & - & - & - & - & - & - \\
\hline Chimney with damper & 2 & - & - & - & - & - & - & - & - \\
\hline $\begin{array}{l}\text { Heat exchanger combined with a hot water } \\
\text { storage }\end{array}$ & 1 & 1 & - & - & - & - & - & - & 1 \\
\hline Absorption chiller & - & 1 & - & - & - & - & - & - & - \\
\hline Condensate recovery system & - & - & - & 1 & - & - & - & - & - \\
\hline
\end{tabular}


Table 5. Scheme of pasteurized milk manufacturing process and low-temperature waste heat sources after validation and contextualization via the analysis of energy audits.

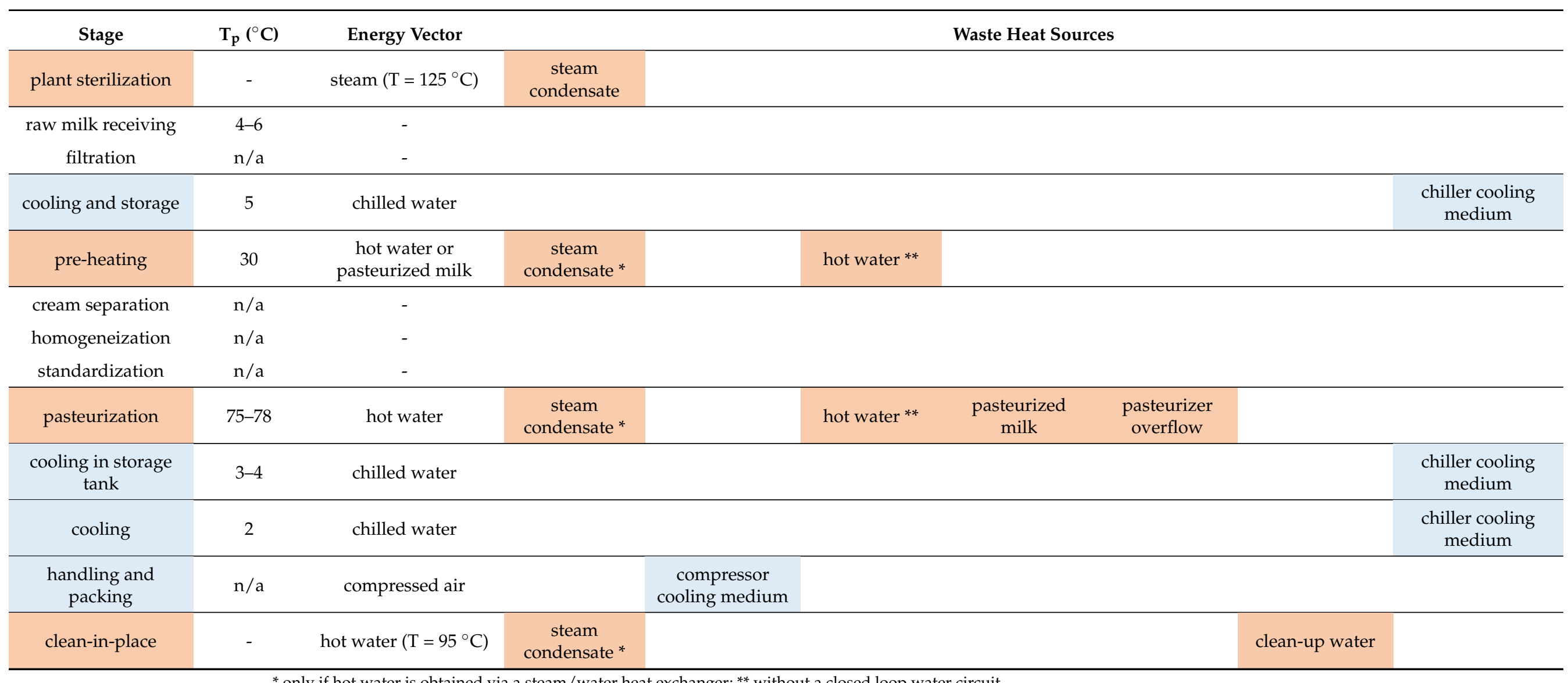

${ }^{*}$ only if hot water is obtained via a steam/water heat exchanger; ${ }^{* *}$ without a closed loop water circuit. 
Specifically, process stages involving the generation of waste heat were divided into two main categories, namely stages with "direct waste heat generation" and stages with "indirect waste heat generation". The formers (highlighted in orange color) allow for the production of low-temperature waste heat by means of an energy vector or through the intermediate or the final products obtained. By way of example, the pasteurization stage is responsible for the generation of four waste heat streams, at different pressure and temperature conditions, namely:

- the condensates from the steam used to heat the water for milk pasteurization;

- the hot water exiting the pasteurizer (only without a closed loop circuit);

- $\quad$ the pasteurized milk;

- $\quad$ the pasteurizer overflow.

Process stages with "indirect waste heat generation" (highlighted in light blue color) are responsible for the release of waste heat because of the auxiliary systems supporting the production process; in the case of the pasteurized milk processing, phases with "indirect waste heat generation" include those requiring chilled water at different temperature levels (storage, cooling after pasteurization) or compressed air (handling, packing, etc.). Indeed, the chilled water production is responsible for the release of waste heat at the chiller condenser, while the compressed air production causes the generation of waste heat that must be removed to ensure proper compressor operating conditions, as well as a compressed air temperature suitable for plant use.

Overall, seven different waste heat streams were identified, including (in order of decreasing temperature) the steam condensate, the compressor cooling medium, the hot water exiting the pasteurizer, the pasteurized milk, the pasteurizer overflow, the cleanup water and the chiller cooling medium. Finally, waste heat acceptors were identified based on the information from literature review and the analysis of waste heat recovery interventions envisaged by dairy enterprises in the context of energy audits (Section 3.1.2). In this regard, Table 6, besides providing a thermodynamic characterization of waste heat streams based on data available in literature, allows to relate waste heat streams to potential technologies for waste heat recovery and possible waste heat acceptors, identified within the process itself, the auxiliary systems and systems for other uses, including space heating, domestic hot water production, etc.

The methodology proposed in this study was also applied to dairy products other than pasteurized milk. Thus, based on data from literature and the information gathered from the analysis of energy audits of dairy enterprises, two different schemes were identified for UHT milk, pasteurized cream, butter, hard cheese and yogurt:

- a scheme of product manufacturing process and low-temperature waste heat sources;

- a scheme providing the thermodynamic characterization of waste heat streams and the identification of possible waste heat recovery technologies and waste heat acceptors. Please refer to Appendix A of this paper for details. 
Table 6. Scheme providing the characterization of waste heat sources from raw milk pasteurization and the identification of possible heat sinks.

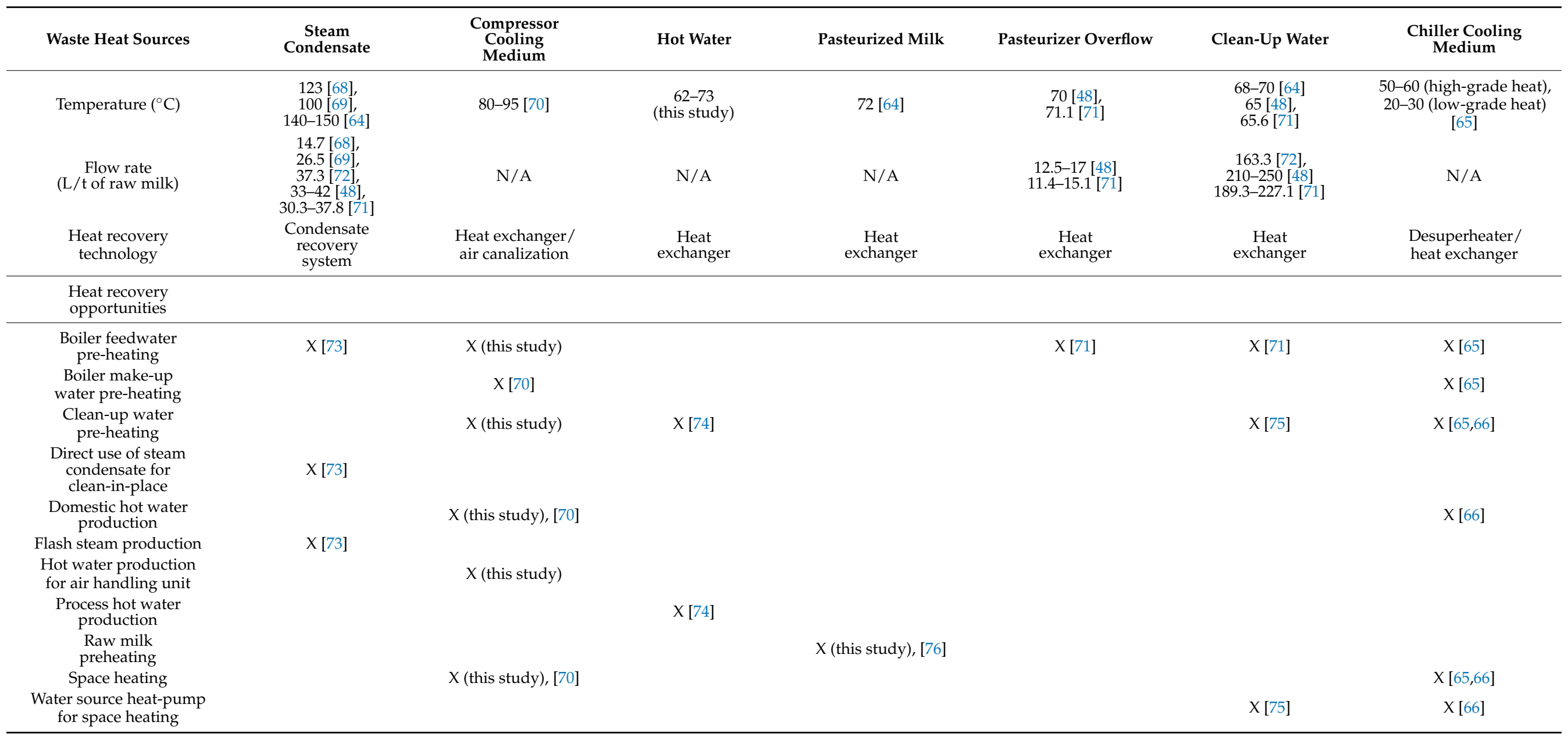


The identification and characterization of waste heat sources represents the preliminary fundamental step in the design of waste heat recovery systems. As an example, the case of an Italian dairy industry, which applied the proposed methodology to completely map the waste heat recovery sources related to the yogurt manufacturing, is here presented. Among the waste heat recovery sources identified within the process investigated, the attention was focused on two main streams: the milk coming out from the aging tank (Case 1) and the cooling medium of the compressed air system (Case 2). Thus, two waste heat recovery projects were envisaged: in Case 1, waste heat recovered via a heat exchanger was reused for heating the water intended for the clean-in-place (CIP) of process equipment; in Case 2 , the waste heat recovered via a heat exchanger was collected in a storage tank and then supplied to the CIP system and the air handling unit (AHU). Characteristics of waste heat recovery sources and sinks, as well as the energy and economic performances of waste heat recovery interventions, were summarized in Table 7 . All data reported in this section have been anonymized and also multiplied by a random factor due to their confidential nature.

Table 7. Energy and economic performances of two waste heat recovery projects envisaged by an Italian dairy industry that applied the methodology here proposed to map the availability of waste heat sources within its facility.

\begin{tabular}{|c|c|c|}
\hline & Case 1 & Case 2 \\
\hline Waste heat source & $\begin{array}{l}\text { Milk coming out } \\
\text { of the aging tank }\end{array}$ & $\begin{array}{l}\text { Cooling medium of } \\
\text { compressed air system }\end{array}$ \\
\hline $\mathrm{T}_{\mathrm{WHS}, \text { in }}\left({ }^{\circ} \mathrm{C}\right)$ & 90 & 90 \\
\hline $\mathrm{T}_{\mathrm{WHS}, \text { out }}\left({ }^{\circ} \mathrm{C}\right)$ & 40 & 27 \\
\hline $\begin{array}{c}\text { Waste heat recovery } \\
\text { technology }\end{array}$ & Heat exchanger & $\begin{array}{l}\text { Heat exchanger combined } \\
\text { with a storage tank }\end{array}$ \\
\hline Waste heat recovered ${ }^{*}(\%)$ & $\approx 60$ & $\approx 80$ \\
\hline Waste heat sink & Cleaning water & $\begin{array}{l}\text { Cleaning water/ water of air } \\
\text { handling unit (AHU) }\end{array}$ \\
\hline $\begin{array}{l}\text { Natural gas saving } \\
\left(\mathrm{Sm}^{3} / \text { year }\right)\end{array}$ & 60,300 & 23,517 \\
\hline Investment cost ${ }^{* *}(€)$ & 17,085 & 25,125 \\
\hline Pay-back time ${ }^{* *}$ (years) & 1.11 & 3.92 \\
\hline
\end{tabular}

\section{Conclusions}

The paper describes an innovative methodology for the systematic mapping of lowtemperature waste heat sources and their potential acceptors in industrial manufacturing processes. The proposed approach is based on a careful analysis and elaboration of data available in technical literature. Such information is enriched and validated using data from real industrial facilities, gathered from the energy audits received by ENEA in compliance with the Legislative Decree 102/2014. The methodology is divided into four main steps: preliminary definition of a typical production process, identification of process phases with low-temperature waste-heat generation, assessment of waste heat sources and potential sinks at phase-level and, lastly, validation, enrichment and contextualization of the outcomes of the methodology via the analysis of the energy audits.

The schemes generated via the application of proposed methodology will contribute to filling the existing knowledge gap on low-temperature waste heat sources in industrial processes, thus promoting the application of waste heat recovery projects. Specifically, the schemes will facilitate to locate and characterize sources of low-temperature waste heat in industrial facilities, and to define solutions for their internal or external reuse and valorization. The schemes will also support academics and legislators in evaluating the waste heat recovery potential in specific industrial sectors, assessing the penetration rate of certain technologies and designing incentive programs for accelerating the implementation of innovative waste heat recovery solutions. 
The methodology has been applied to the Italian dairy sector, because of its enormous potential for the utilization of low-temperature waste heat sources, and the resulting schemes referred to the manufacturing of the main dairy products (pasteurized milk, UHT milk, cream, butter, hard cheese and yogurt) have been produced and presented. Focusing on the case of pasteurized milk, the comparison between literature and energy audit data confirmed that main sources of waste heat are located within the pasteurization stage (steam condensate, hot water at pasteurizer exit, pasteurized milk, pasteurizer overflow). Additional sources of waste heat are related to the auxiliary systems. Namely, they are the cooling mediums of compressed air and chilled water systems, which are required to ensure the optimal operating conditions of such devices.

The analysis of energy audits, besides providing additional information on types and characteristics of low-temperature waste heat sources, highlighted that dairy manufacturers are mainly interested in implementing solutions to recover waste heat within the industrial facility itself. Specifically, waste heat is recovered within the auxiliary systems (intended for steam, compressed air and cold water production), with the aim to improve their efficiency or to support space heating or the production of hot water for equipment cleaning or domestic purposes. Heat exchangers, with or without storage systems, are by far the most common technology to capture and deliver waste heat as useful energy where it is needed. On the other side, the use of technologies to convert the waste heat into electricity still remains unexplored.

The study highlighted that the comparison with data from industrial companies is essential for improving the accuracy, the usability and the applicability of schemes of low-temperature waste heat sources and sinks.

Although those schemes were obtained on the basis of data gathered from Italian enterprises, they can be regarded as a starting point for the investigation of dairy industry in other countries. Furthermore, the methodology can be applied to any industrial sector, provided that data of sufficient quantity and/or quality from industrial companies are available.

The methodology proposed in this study is part of a wider project aimed at developing a decision support tool, which will allow industrial companies to preliminary identify low-temperature waste heat recovery opportunities and compare their performances from the energy, environmental and economic perspectives. The software tool will be supported by data regarding conversion efficiency, energy savings and costs of waste heat recovery interventions gathered from the analysis of literature and energy audits. Within this project, the schemes of low-temperature waste heat sources and sinks will be further validated via a direct interaction with industrial companies. This will provide the opportunity to collect data from smaller enterprises, thus broadening the scope of the schemes of low-temperature waste heat sources and sinks derived from the application of this methodology.

Future research directions will include:

- the modelization of waste heat sources fluctuation and intermittency in both mass or volume flow rate and temperature; such aspect has been rarely investigated in the technical literature, even though it is expected to affect to a certain extent the techno-economic performances of waste heat recovery technologies, depending on the frequency of parameters variations;

- the development of tools for the real-time optimization of waste heat recovery system performances;

- the full integration of the schemes of waste heat sources within the decision support tool under development, with aim to assist the user in the identification and characterization of available waste heat sources varying the type of industrial process investigated;

- the use of these schemes to support the knowledge dissemination and the networking among companies, with the aim to overcome technological barriers to the implementation of waste heat recovery systems. 
Author Contributions: Conceptualization, L.G. and M.B.; methodology, L.G.; validation, L.G.; writing-original draft preparation, L.G.; writing-review and editing, L.G. and M.B. All authors have read and agreed to the published version of the manuscript.

Funding: This work is part of the Program “Electrical System Research 2019-2021", implemented under Program Agreements between the Italian Ministry for Economic Development and ENEA, CNR, and RSE S.p.A, Project 1.6 "Energy efficiency of industrial products and processes", WP3.

Conflicts of Interest: The authors declare no conflict of interest.

\section{Appendix A}

The appendix contains the schemes of product manufacturing process and the corresponding low-temperature waste heat sources and the schemes providing the characterization of low-temperature waste heat sources and the possible waste heat sinks related to dairy products other than pasteurized milk, such as UHT milk, cream, butter, hard cheese and yogurt production.

Table A1. Scheme of UHT milk manufacturing process and corresponding low-temperature waste heat sources.

\begin{tabular}{|c|c|c|c|c|c|c|c|c|}
\hline Stage & $\mathrm{T}_{\mathrm{p}}\left({ }^{\circ} \mathrm{C}\right)$ & Energy Vector & \multicolumn{6}{|c|}{ Waste Heat Sources } \\
\hline raw milk receiving & 10 & - & & & & & & \\
\hline storage & 10 & - & & & & & & \\
\hline pre-heating & 50 & $\begin{array}{l}\text { hot water or } \\
\text { UHT milk }\end{array}$ & $\begin{array}{c}\text { steam } \\
\text { condensate }\end{array}$ & & & hot water ${ }^{* *}$ & & \\
\hline separation & $\mathrm{n} / \mathrm{a}$ & - & & & & & & \\
\hline homogenization & $\mathrm{n} / \mathrm{a}$ & - & & & & & & \\
\hline standardization & $\mathrm{n} / \mathrm{a}$ & - & & & & & & \\
\hline $\begin{array}{l}\text { cooling in storage } \\
\text { tank }\end{array}$ & $4-5$ & chilled water & & & & & & $\begin{array}{l}\text { chiller cooling } \\
\text { medium }\end{array}$ \\
\hline 1st pre-heating & 27 & $\begin{array}{l}\text { hot water or } \\
\text { UHT milk }\end{array}$ & & & & & & \\
\hline 2nd pre-heating & 35 & $\begin{array}{c}\text { steam } \\
\text { condensate }\end{array}$ & & & & & & \\
\hline pasteurization & 85 & $\begin{array}{c}\text { steam } \\
\left(\mathrm{T}=100^{\circ} \mathrm{C}\right)\end{array}$ & $\begin{array}{c}\text { steam } \\
\text { condensate }\end{array}$ & & & & & \\
\hline sterilization & $\mathrm{n} / \mathrm{a}$ & $\begin{array}{c}\text { steam } \\
\left(\mathrm{T}=150{ }^{\circ} \mathrm{C}\right)\end{array}$ & & & & & & \\
\hline $\begin{array}{l}\text { steam separation } \\
\text { (via degasser) }\end{array}$ & 90 & - & $\begin{array}{c}\text { steam } \\
\text { condensate }\end{array}$ & $\begin{array}{l}\text { sterilized } \\
\text { milk }\end{array}$ & & & & \\
\hline homogenization & $\mathrm{n} / \mathrm{a}$ & - & & & & & & \\
\hline cooling & 26 & chilled water & & & & & & $\begin{array}{l}\text { chiller cooling } \\
\text { medium }\end{array}$ \\
\hline storage & 26 & - & & & & & & \\
\hline $\begin{array}{l}\text { handling and } \\
\text { packing }\end{array}$ & $\mathrm{n} / \mathrm{a}$ & compressed air & & & $\begin{array}{c}\text { compressor } \\
\text { cooling medium }\end{array}$ & & & \\
\hline clean-in-place & - & $\begin{array}{l}\text { hot water } \\
\left(\mathrm{T}=95^{\circ} \mathrm{C}\right)\end{array}$ & $\begin{array}{c}\text { steam } \\
\text { condensate }\end{array}$ & & & & $\begin{array}{l}\text { clean-up } \\
\text { water }\end{array}$ & \\
\hline
\end{tabular}

${ }^{*}$ only if hot water is obtained via a steam/water heat exchanger; ${ }^{* *}$ without a closed loop water circuit. 
Table A2. Scheme providing the characterization of waste heat sources from UHT milk production and the identification of possible heat sinks.

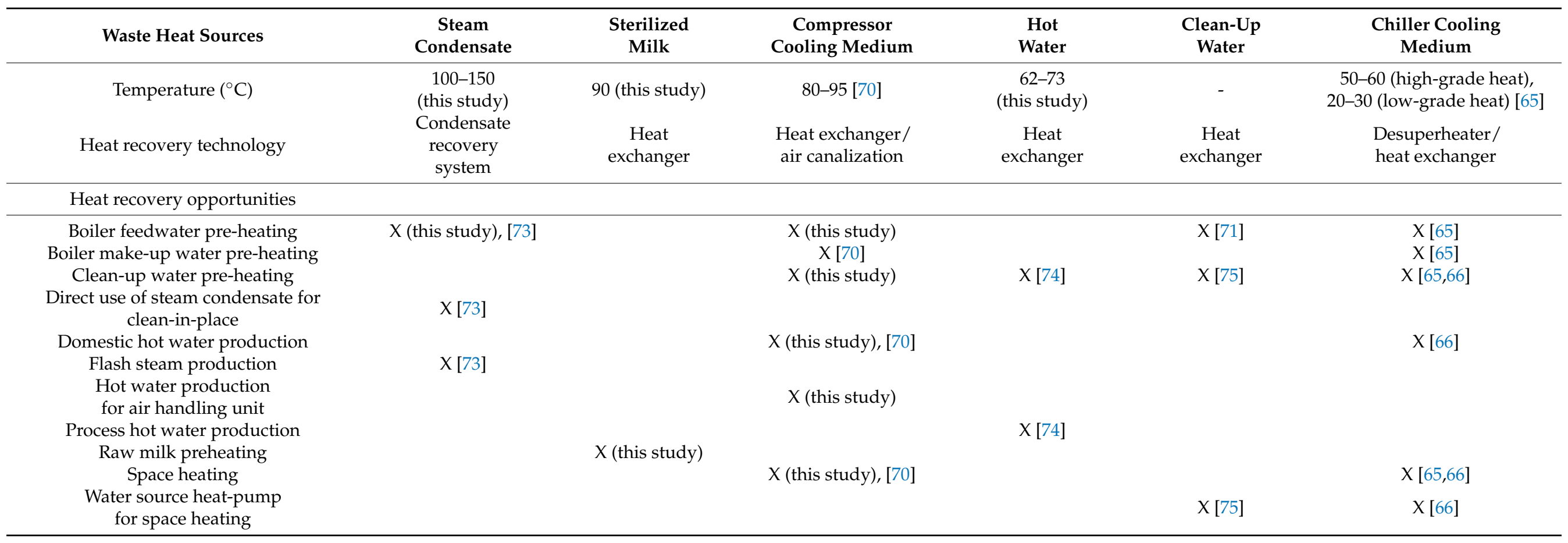


Table A3. Scheme of pasteurized cream manufacturing process and corresponding low-temperature waste heat sources.

\begin{tabular}{|c|c|c|c|c|c|c|c|c|}
\hline Stage & $\mathrm{T}_{\mathrm{p}}\left({ }^{\circ} \mathrm{C}\right)$ & Energy Vector & \multicolumn{6}{|c|}{ Waste Heat Sources } \\
\hline plant sterilization & - & $\begin{array}{c}\text { steam }\left(\mathrm{T}=125^{\circ} \mathrm{C}\right) \\
\text { or hot water } \\
\left(\mathrm{T}=84{ }^{\circ} \mathrm{C}\right)\end{array}$ & $\begin{array}{c}\text { steam } \\
\text { condensate * }\end{array}$ & & hot water & & & \\
\hline aging & 50 & - & & & & & & \\
\hline pasteurization & $80-98$ & hot water & $\begin{array}{c}\text { steam } \\
\text { condensate * }\end{array}$ & & hot water ** & pasteurized cream & & \\
\hline $\begin{array}{c}\text { storage in agitated } \\
\text { tank }\end{array}$ & 5 & chilled water & & & & & & $\begin{array}{l}\text { chiller cooling } \\
\text { medium }\end{array}$ \\
\hline $\begin{array}{l}\text { handling and } \\
\text { packing }\end{array}$ & $\mathrm{n} / \mathrm{a}$ & compressed air & & $\begin{array}{l}\text { compressor } \\
\text { cooling } \\
\text { medium } \\
\end{array}$ & & & & \\
\hline clean-in-place & - & $\begin{array}{l}\text { hot water } \\
\left(\mathrm{T}=95^{\circ} \mathrm{C}\right)\end{array}$ & $\begin{array}{c}\text { steam } \\
\text { condensate * }\end{array}$ & & & & clean-up water & \\
\hline
\end{tabular}

${ }^{*}$ only if hot water is obtained via a steam/water heat exchanger; ${ }^{* *}$ without a closed loop water circuit. 
Table A4. Scheme providing the characterization of waste heat sources from pasteurized cream production and the identification of possible heat sinks.

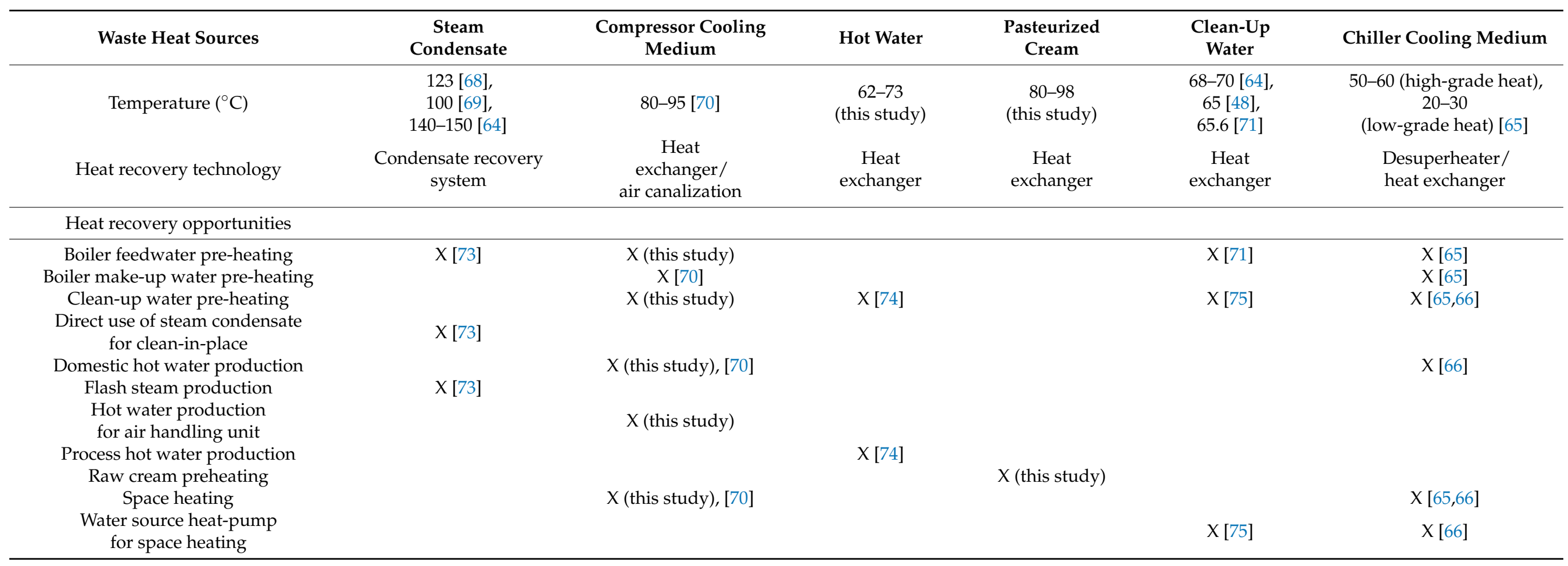


Table A5. Scheme of butter manufacturing process and corresponding low-temperature waste heat sources.

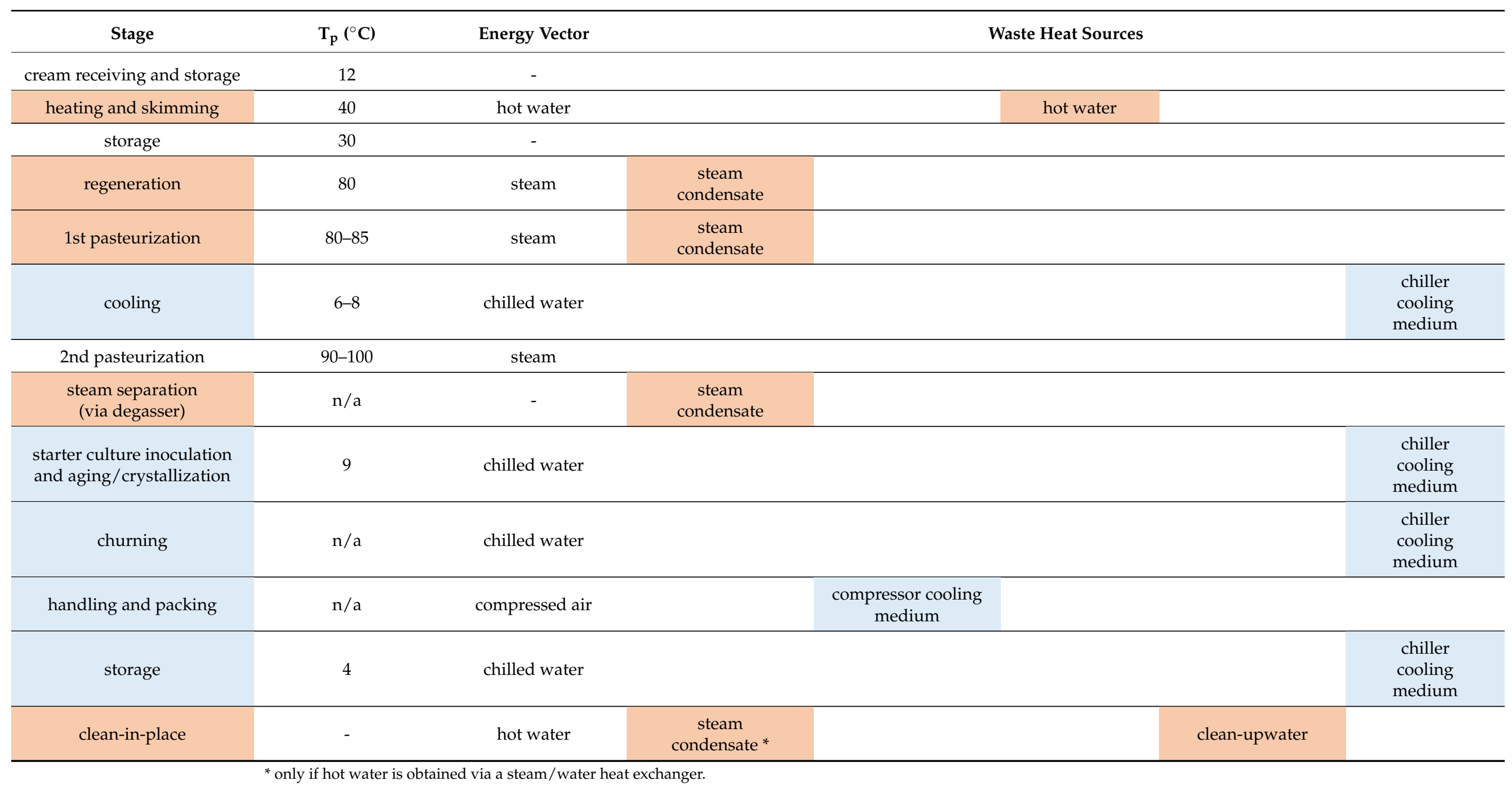

${ }^{*}$ only if hot water is obtained via a steam/water heat exchanger 
Table A6. Scheme providing the characterization of waste heat sources from butter production and the identification of possible heat sinks.

\begin{tabular}{|c|c|c|c|c|c|}
\hline Waste Heat Sources & $\begin{array}{c}\text { Steam } \\
\text { Condensate }\end{array}$ & $\begin{array}{l}\text { Compressor } \\
\text { Cooling } \\
\text { Medium }\end{array}$ & Hot Water & $\begin{array}{l}\text { Clean-Up } \\
\text { Water }\end{array}$ & $\begin{array}{l}\text { Chiller } \\
\text { Cooling } \\
\text { Medium }\end{array}$ \\
\hline Temperature $\left({ }^{\circ} \mathrm{C}\right)$ & $\begin{array}{c}123[68], \\
100[69], \\
140-150[64]\end{array}$ & $80-95[70]$ & $\begin{array}{c}62-73 \\
\text { (this study) }\end{array}$ & $\begin{array}{c}68-70[64], \\
65[48], \\
65.6[71]\end{array}$ & $\begin{array}{l}\text { 50-60 (high-grade heat), } \\
\text { 20-30 (low-grade heat) [65] }\end{array}$ \\
\hline Heat recovery technology & $\begin{array}{c}\text { Condensate } \\
\text { recovery } \\
\text { system }\end{array}$ & $\begin{array}{l}\text { Heat exchanger/ } \\
\text { air canalization }\end{array}$ & $\begin{array}{l}\text { Heat } \\
\text { exchanger }\end{array}$ & $\begin{array}{l}\text { Heat } \\
\text { exchanger }\end{array}$ & $\begin{array}{l}\text { Desuperheater/ } \\
\text { heat exchanger }\end{array}$ \\
\hline \multicolumn{6}{|l|}{ Heat recovery opportunities } \\
\hline Boiler feedwater pre-heating & $X[73]$ & X (this study) & & $X[71]$ & $X[65]$ \\
\hline Boiler make-up water pre-heating & & $X[70]$ & & & $X[65]$ \\
\hline Clean-up water pre-heating & & $X$ (this study) & $X[74]$ & $X[75]$ & $X[65,66]$ \\
\hline $\begin{array}{l}\text { Direct use of steam condensate for } \\
\text { clean-in-place }\end{array}$ & $X[73]$ & & & & \\
\hline Domestic hot water production & & X (this study), [70] & & & $X[66]$ \\
\hline Flash steam production & $X[73]$ & & & & \\
\hline $\begin{array}{l}\text { Hot water production } \\
\text { for air handling unit }\end{array}$ & & X (this study) & & & \\
\hline Process hot water production & & & $X[74]$ & & \\
\hline Space heating & & X (this study), [70] & & & $X[65,66]$ \\
\hline $\begin{array}{l}\text { Water source heat-pump } \\
\text { for space heating }\end{array}$ & & & & $X[75]$ & X [66] \\
\hline
\end{tabular}


Table A7. Scheme of hard cheese manufacturing process and corresponding low-temperature waste heat sources.

\begin{tabular}{|c|c|c|c|c|c|c|c|c|}
\hline Stage & $\mathrm{T}_{\mathrm{p}}\left({ }^{\circ} \mathrm{C}\right)$ & Energy Vector & \multicolumn{6}{|c|}{ Waste Heat Sources } \\
\hline raw milk receiving & 4 & - & & & & & & \\
\hline filtration & $\mathrm{n} / \mathrm{a}$ & - & & & & & & \\
\hline $\begin{array}{l}\text { cooling and } \\
\text { storage }\end{array}$ & $\mathrm{n} / \mathrm{a}$ & chilled water & & & & & & $\begin{array}{l}\text { chiller cooling } \\
\text { medium }\end{array}$ \\
\hline pre-heating & $50-55$ & hot water & $\begin{array}{c}\text { steam } \\
\text { condensate * }\end{array}$ & & $\begin{array}{c}\text { hot } \\
\text { water ** }\end{array}$ & & & \\
\hline skimming & $\mathrm{n} / \mathrm{a}$ & - & & & & & & \\
\hline bactofugation & $\mathrm{n} / \mathrm{a}$ & - & & & & & & \\
\hline $\begin{array}{l}\text { cooling and } \\
\text { storage }\end{array}$ & $10-15$ & chilled water & & & & & & $\begin{array}{l}\text { chiller cooling } \\
\text { medium }\end{array}$ \\
\hline $\begin{array}{l}\text { whey starter and } \\
\text { curd addition } \\
\text { (in cheese kettle) }\end{array}$ & $\mathrm{n} / \mathrm{a}$ & - & & & & & & \\
\hline cooking & $20-55$ & steam & $\begin{array}{c}\text { steam } \\
\text { condensate }\end{array}$ & & & & & \\
\hline coagulation & $\mathrm{n} / \mathrm{a}$ & - & & & & & & \\
\hline $\begin{array}{l}\text { curd breaking andwhey } \\
\text { separation }\end{array}$ & $\mathrm{n} / \mathrm{a}$ & - & & & & & whey & \\
\hline moulds turning & $\mathrm{n} / \mathrm{a}$ & - & & & & & & \\
\hline $\begin{array}{c}\text { resting } \\
\text { (hot chamber) }\end{array}$ & 38 & steam & $\begin{array}{c}\text { steam } \\
\text { condensate }\end{array}$ & & & & & \\
\hline transfer to cold chamber & $\mathrm{n} / \mathrm{a}$ & - & & & & & & \\
\hline salting & 10 & chilled water & & & & & & $\begin{array}{l}\text { chiller cooling } \\
\text { medium }\end{array}$ \\
\hline $\begin{array}{c}\text { drying and } \\
\text { ripening }\end{array}$ & $\mathrm{n} / \mathrm{a}$ & steam & $\begin{array}{c}\text { steam } \\
\text { condensate }\end{array}$ & & & & & \\
\hline $\begin{array}{c}\text { washing and } \\
\text { surface treatment }\end{array}$ & $\mathrm{n} / \mathrm{a}$ & - & & & & & & \\
\hline $\begin{array}{l}\text { handling and } \\
\text { packing }\end{array}$ & $\mathrm{n} / \mathrm{a}$ & compressed air & & $\begin{array}{l}\text { compressor } \\
\text { cooling } \\
\text { medium }\end{array}$ & & & & \\
\hline storage & $\mathrm{n} / \mathrm{a}$ & - & & & & & & \\
\hline clean-in-place & - & hot water & $\begin{array}{c}\text { steam } \\
\text { condensate* }\end{array}$ & & & & clean-up water & \\
\hline
\end{tabular}

* only if hot water is obtained via a steam/water heat exchanger; ${ }^{* *}$ without a closed loop water circuit. 
Table A8. Scheme providing the characterization of waste heat sources from hard cheese production and the identification of possible heat sinks.

\begin{tabular}{|c|c|c|c|c|c|c|c|c|}
\hline Waste Heat Sources & $\begin{array}{c}\text { Steam } \\
\text { Condensate }\end{array}$ & $\begin{array}{c}\text { Compressor Cooling } \\
\text { Medium }\end{array}$ & Hot Water & Pasteurized Milk & $\begin{array}{l}\text { Pasteurizer } \\
\text { Overflow }\end{array}$ & Clean-Up Water & Whey & $\begin{array}{l}\text { Chiller } \\
\text { Cooling } \\
\text { Medium }\end{array}$ \\
\hline Temperature $\left({ }^{\circ} \mathrm{C}\right)$ & $\begin{array}{c}123[68], \\
100[69], \\
140-150[64]\end{array}$ & $80-95[70]$ & $\begin{array}{c}62-73 \\
\text { (this study) }\end{array}$ & $72[64]$ & $\begin{array}{l}70[48] \\
71.1[71]\end{array}$ & $60[48,71]$ & $38[48,71]$ & $\begin{array}{c}\text { 50-60 (high-grade heat), } \\
20-30 \\
\text { (low-grade heat) [65] }\end{array}$ \\
\hline $\begin{array}{c}\text { Flow rate } \\
\text { (l/t of raw milk) }\end{array}$ & $\begin{array}{l}150[48] \\
136.3[71]\end{array}$ & $\mathrm{N} / \mathrm{A}$ & $\mathrm{N} / \mathrm{A}$ & $\mathrm{N} / \mathrm{A}$ & $\begin{array}{c}13[48] \\
12.1[71]\end{array}$ & $\begin{array}{c}250-545[48] \\
227.1-492.1[71]\end{array}$ & $\begin{array}{l}993[48], \\
900[71]\end{array}$ & N/A \\
\hline Heat recovery technology & $\begin{array}{l}\text { Condensaterecovery } \\
\text { system }\end{array}$ & $\begin{array}{c}\text { Heat } \\
\text { exchanger/ } \\
\text { air canalization }\end{array}$ & $\begin{array}{c}\text { Heat } \\
\text { exchanger }\end{array}$ & 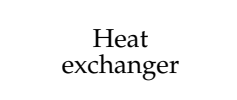 & $\begin{array}{l}\text { Heat } \\
\text { exchanger/ } \\
\text { direct use }\end{array}$ & $\begin{array}{c}\begin{array}{c}\text { Heat } \\
\text { exchanger }\end{array} \\
\text { excin }\end{array}$ & $\begin{array}{c}\begin{array}{c}\text { Heat } \\
\text { exchanger }\end{array} \\
\text { excin }\end{array}$ & $\begin{array}{l}\text { Desuperheater/heat } \\
\text { exchanger }\end{array}$ \\
\hline \multicolumn{9}{|l|}{ Heat recovery opportunities } \\
\hline Boiler feedwater pre-heating & $X[73]$ & X (this study) & & & $X[71]$ & $X[71]$ & $X[71]$ & $X[65]$ \\
\hline $\begin{array}{l}\text { Boiler make-up water } \\
\text { pre-heating }\end{array}$ & & $X[70]$ & & & & & & $X[65]$ \\
\hline Clean-up water pre-heating & & X (this study) & $X[74]$ & & & $\mathrm{X}[75]$ & & $X[65,66]$ \\
\hline $\begin{array}{l}\text { Direct use of steam } \\
\text { condensate for clean-in-place }\end{array}$ & $X[73]$ & & & & & & & \\
\hline $\begin{array}{l}\text { Domestic hot water } \\
\text { production }\end{array}$ & & X (this study), [70] & & & & & & $\mathrm{X}[66]$ \\
\hline Flash steam production & $X[73]$ & & & & & & & \\
\hline Process hot water production & & & $X[74]$ & & & & & \\
\hline Raw milk preheating & & & & X (this study), [76] & & & & \\
\hline Space heating & & X (this study), [70] & & & & & & $X[65,66]$ \\
\hline $\begin{array}{l}\text { Water source heat-pump } \\
\text { for space heating }\end{array}$ & & & & & & $X[75]$ & & $X[66]$ \\
\hline
\end{tabular}


Table A9. Scheme of yoghurt manufacturing process and corresponding low-temperature waste heat sources.

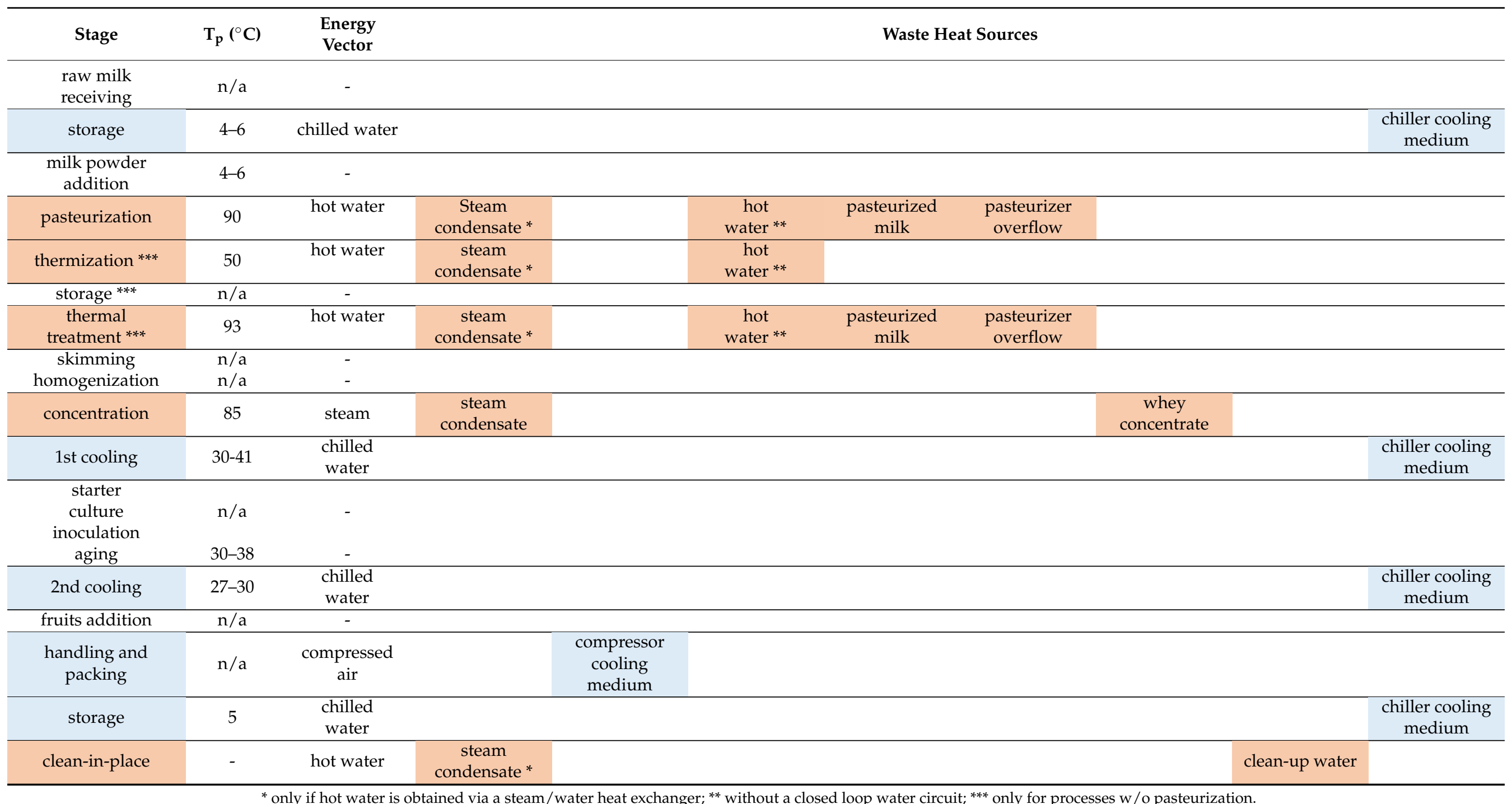


Table A10. Scheme providing the characterization of waste heat sources from yoghurt production and the identification of possible heat sinks.

\begin{tabular}{|c|c|c|c|c|c|c|c|c|}
\hline Waste Heat Sources & $\begin{array}{l}\text { Steam } \\
\text { Condensate }\end{array}$ & $\begin{array}{l}\text { Compressor } \\
\text { Cooling } \\
\text { Medium }\end{array}$ & Hot Water & Pasteurized Milk & $\begin{array}{l}\text { Pasteurizer } \\
\text { Overflow }\end{array}$ & $\begin{array}{c}\text { Whey } \\
\text { Concentrate }\end{array}$ & Clean-Up Water & $\begin{array}{l}\text { Chiller } \\
\text { Cooling } \\
\text { Medium }\end{array}$ \\
\hline Temperature $\left({ }^{\circ} \mathrm{C}\right)$ & $\begin{array}{c}123[68], \\
100[69], \\
140-150[64]\end{array}$ & $80-95[70]$ & $\begin{array}{c}62-73 \\
\text { (this study) }\end{array}$ & $72[64]$ & $\begin{array}{l}70[48], \\
71.1[71]\end{array}$ & $55-68[77]$ & $\begin{array}{c}68-70[64] \\
65[48] \\
65.6[71]\end{array}$ & $\begin{array}{c}\text { 50-60 (high-grade } \\
\text { heat), 20-30 } \\
\text { (low-grade heat) [65] }\end{array}$ \\
\hline $\begin{array}{l}\text { Heat recovery } \\
\text { technology }\end{array}$ & $\begin{array}{l}\text { Condensate recovery } \\
\text { system }\end{array}$ & $\begin{array}{c}\text { Heat } \\
\text { exchanger/air } \\
\text { canalization }\end{array}$ & $\begin{array}{c}\text { Heat } \\
\text { exchanger }\end{array}$ & $\begin{array}{c}\text { Heat } \\
\text { exchanger }\end{array}$ & $\begin{array}{l}\text { Heat } \\
\text { exchanger }\end{array}$ & $\begin{array}{c}\text { Heat } \\
\text { exchanger network }\end{array}$ & $\begin{array}{c}\text { Heat } \\
\text { exchanger }\end{array}$ & $\begin{array}{c}\text { Desuperheater/ } \\
\text { heat } \\
\text { exchanger }\end{array}$ \\
\hline \multicolumn{9}{|l|}{$\begin{array}{l}\text { Heat recovery } \\
\text { opportunities }\end{array}$} \\
\hline $\begin{array}{l}\text { Boiler feedwater } \\
\text { pre-heating }\end{array}$ & $X[73]$ & X (this study) & & & $\mathrm{X}[71]$ & & $X[71]$ & $X[65]$ \\
\hline $\begin{array}{l}\text { Boiler make-up water } \\
\text { pre-heating }\end{array}$ & & $X[70]$ & & & & & & $X[65]$ \\
\hline $\begin{array}{l}\text { Clean-up water } \\
\text { pre-heating }\end{array}$ & & X (this study) & $X[74]$ & & & & $X[75]$ & $X[65,66]$ \\
\hline $\begin{array}{l}\text { Direct use of steam } \\
\text { condensate } \\
\text { for clean-in-place }\end{array}$ & $X[73]$ & & & & & & & \\
\hline $\begin{array}{l}\text { Domestic hot water } \\
\text { production }\end{array}$ & & X (this study), [70] & & & & & & $X[66]$ \\
\hline $\begin{array}{l}\text { Hot water production for air } \\
\text { handling unit }\end{array}$ & & X (this study) & & & & & & \\
\hline $\begin{array}{l}\text { Process hot water } \\
\text { production }\end{array}$ & & & $X[74]$ & & & & & \\
\hline Raw milk preheating & & & & $\begin{array}{c}\text { X (this study), } \\
{[76]}\end{array}$ & & & & \\
\hline Space heating & & X (this study), [70] & & & & & & $X[65,66]$ \\
\hline $\begin{array}{l}\text { Standardized milk } \\
\text { pre-heating }\end{array}$ & & & & & & $\mathrm{X}[77]$ & & \\
\hline $\begin{array}{l}\text { Water source heat-pump for space } \\
\text { heating }\end{array}$ & & & & & & & $X[75]$ & $X[66]$ \\
\hline
\end{tabular}




\section{References}

1. European Commission. Communication from the Commission to the European Parliament, the Council, the European Economic and Social Committee, the Committee of the Regions and the European Investment Bank Clean Energy for all Europeans COM/2016/0860 Final 2016. Available online: https:/ / eur-lex.europa.eu/legal-content/en/TXT/?uri=CELEX:52016DC0860 (accessed on 5 October 2021).

2. European Commission. Directive (Eu) 2018/2002 of the European Parliament and of the Council of 11 December 2018 (Amending Directive 2012/27/EU on Energy Efficiency) 2018. Available online: https:/ / eur-lex.europa.eu/legal-content/EN/TXT/?uri= uriserv\%3AOJ.L_.2018.328.01.0210.01.ENG (accessed on 5 October 2021).

3. European Commission. Communication from the Commission to the European Parliament, the Council, the European Economic and Social Committee and the Committee of the Regions. "Fit for 55": Delivering the EU's 2030 Climate Target on the Way to Climate Neutrality 2021. Available online: https:/ / eur-lex.europa.eu/legal-content/EN/TXT/?uri=CELEX\%3A52021DC0550 (accessed on 5 October 2021).

4. European Commission. Directive of the European Parliament and of the Council on Energy Efficiency (Recast) 2021. Available online: https:/ / eur-lex.europa.eu/legal-content/EN/TXT/?uri=CELEX\%3A52021PC0558 (accessed on 5 October 2021).

5. Eurostat-Statistic Explained Energy Statistics-An Overview. Available online: https://ec.europa.eu/eurostat/statisticsexplained/index.php?title=Energy_statistics_-_an_overview (accessed on 5 October 2021).

6. European Environment Agency EEA Greenhouse Gases-Data Viewer-European Environment Agency. Available online: https:/ / www.eea.europa.eu/data-and-maps/data/data-viewers/greenhouse-gases-viewer (accessed on 5 October 2021).

7. European Commission. Communication from the Commission to the European Parliament, the Council, the European Economic and Social Committee and the Committee of the Regions. Powering a Climate-Neutral Economy: An EU Strategy for Energy System Integration 2020. Available online: https:/ / eur-lex.europa.eu/legal-content/EN/ALL/?uri=COM:2020:299:FIN (accessed on 5 October 2021)

8. Simeone, A.; Luo, Y.; Woolley, E.; Rahimifard, S.; Boër, C. A Decision Support System for Waste Heat Recovery in Manufacturing. CIRP Ann. 2016, 65, 21-24. [CrossRef]

9. U.S. Department of Energy Waste Heat Recovery Systems. 14th Manufacturing-FocusedTechnology Assessment in Support of Chapter 6: Innovating Clean Energy Technologies in Advanced Manufacturing. Appendix to the 2015 Quadrennial Technology Review 2015. Available online: https: / www.energy.gov/sites/default/files/2016/02/f30/QTR2015-6M-Waste-Heat-Recovery. pdf (accessed on 7 October 2021).

10. Bianchi, G.; Panayiotou, G.P.; Aresti, L.; Kalogirou, S.A.; Florides, G.A.; Tsamos, K.; Tassou, S.A.; Christodoulides, P. Estimating the Waste Heat Recovery in the European Union Industry. Energ. Ecol. Environ. 2019, 4, 211-221. [CrossRef]

11. Jouhara, H.; Khordehgah, N.; Almahmoud, S.; Delpech, B.; Chauhan, A.; Tassou, S.A. Waste Heat Recovery Technologies and Applications. Therm. Sci. Eng. Prog. 2018, 6, 268-289. [CrossRef]

12. Xu, Z.Y.; Wang, R.Z.; Yang, C. Perspectives for Low-Temperature Waste Heat Recovery. Energy 2019, 176, 1037-1043. [CrossRef]

13. Brückner, S.; Liu, S.; Miró, L.; Radspieler, M.; Cabeza, L.F.; Lävemann, E. Industrial Waste Heat Recovery Technologies: An Economic Analysis of Heat Transformation Technologies. Appl. Energy 2015, 151, 157-167. [CrossRef]

14. Mahmoudi, A.; Fazli, M.; Morad, M.R. A Recent Review of Waste Heat Recovery by Organic Rankine Cycle. Appl. Therm. Eng. 2018, 143, 660-675. [CrossRef]

15. Xia, L.; Liu, R.; Zeng, Y.; Zhou, P.; Liu, J.; Cao, X.; Xiang, S. A Review of Low-Temperature Heat Recovery Technologies for Industry Processes. Chin. J. Chem. Eng. 2019, 27, 2227-2237. [CrossRef]

16. Loni, R.; Najafi, G.; Bellos, E.; Rajaee, F.; Said, Z.; Mazlan, M. A Review of Industrial Waste Heat Recovery System for Power Generation with Organic Rankine Cycle: Recent Challenges and Future Outlook. J. Clean. Prod. 2021, 287, 125070. [CrossRef]

17. Champier, D. Thermoelectric Generators: A Review of Applications. Energy Convers. Manag. 2017, 140, 167-181. [CrossRef]

18. Olabi, A.G.; Elsaid, K.; Sayed, E.T.; Mahmoud, M.S.; Wilberforce, T.; Hassiba, R.J.; Abdelkareem, M.A. Application of Nanofluids for Enhanced Waste Heat Recovery: A Review. Nano Energy 2021, 84, 105871. [CrossRef]

19. Li, Y.; Xia, J.; Fang, H.; Su, Y.; Jiang, Y. Case Study on Industrial Surplus Heat of Steel Plants for District Heating in Northern China. Energy 2016, 102, 397-405. [CrossRef]

20. Fang, H.; Xia, J.; Jiang, Y. Key Issues and Solutions in a District Heating System Using Low-Grade Industrial Waste Heat. Energy 2015, 86, 589-602. [CrossRef]

21. Bonilla-Campos, I.; Nieto, N.; del Portillo-Valdes, L.; Egilegor, B.; Manzanedo, J.; Gaztañaga, H. Energy Efficiency Assessment: Process Modelling and Waste Heat Recovery Analysis. Energy Convers. Manag. 2019, 196, 1180-1192. [CrossRef]

22. Nikolaisen, M.; Andresen, T. System Impact of Heat Exchanger Pressure Loss in ORCs for Smelter Off-Gas Waste Heat Recovery. Energy 2021, 215, 118956. [CrossRef]

23. Peris, B.; Navarro-Esbrí, J.; Molés, F.; Mota-Babiloni, A. Experimental Study of an ORC (Organic Rankine Cycle) for Low Grade Waste Heat Recovery in a Ceramic Industry. Energy 2015, 85, 534-542. [CrossRef]

24. Delpech, B.; Milani, M.; Montorsi, L.; Boscardin, D.; Chauhan, A.; Almahmoud, S.; Axcell, B.; Jouhara, H. Energy Efficiency Enhancement and Waste Heat Recovery in Industrial Processes by Means of the Heat Pipe Technology: Case of the Ceramic Industry. Energy 2018, 158, 656-665. [CrossRef] 
25. Jouhara, H.; Bertrand, D.; Axcell, B.; Montorsi, L.; Venturelli, M.; Almahmoud, S.; Milani, M.; Ahmad, L.; Chauhan, A. Investigation on a Full-Scale Heat Pipe Heat Exchanger in the Ceramics Industry for Waste Heat Recovery. Energy 2021, 223, 120037. [CrossRef]

26. Brough, D.; Mezquita, A.; Ferrer, S.; Segarra, C.; Chauhan, A.; Almahmoud, S.; Khordehgah, N.; Ahmad, L.; Middleton, D.; Sewell, H.I.; et al. An Experimental Study and Computational Validation of Waste Heat Recovery from a Lab Scale Ceramic Kiln Using a Vertical Multi-Pass Heat Pipe Heat Exchanger. Energy 2020, 208, 118325. [CrossRef]

27. Öhman, H. Implementation and Evaluation of a Low Temperature Waste Heat Recovery Power Cycle Using NH3 in an Organic Rankine Cycle. Energy 2012, 48, 227-232. [CrossRef]

28. Savulescu, L.; Périn-Levasseur, Z.; Benali, M. Innovative Visualization Technique for Energy Flow Analysis: Waste Heat Recovery and Energy Savings Opportunities. Appl. Therm. Eng. 2013, 61, 143-148. [CrossRef]

29. Fiaschi, D.; Manfrida, G.; Russo, L.; Talluri, L. Improvement of Waste Heat Recuperation on an Industrial Textile Dryer: Redesign of Heat Exchangers Network and Components. Energy Convers. Manag. 2017, 150, 924-940. [CrossRef]

30. Rakib, M.I.; Saidur, R.; Mohamad, E.N.; Afifi, A.M. Waste-Heat Utilization-The Sustainable Technologies to Minimize Energy Consumption in Bangladesh Textile Sector. J. Clean. Prod. 2017, 142, 1867-1876. [CrossRef]

31. Law, R.; Harvey, A.; Reay, D. A Knowledge-Based System for Low-Grade Waste Heat Recovery in the Process Industries. Appl. Therm. Eng. 2016, 94, 590-599. [CrossRef]

32. Fiaschi, D.; Talluri, L. Assessment of the Thermoelectric Conversion Potential of Low-Temperature Waste Heat from Textile Dry-Cleaning Processes. E3S Web Conf. 2019, 113, 03019. [CrossRef]

33. El Fil, B.; Garimella, S. Waste Heat Recovery in Commercial Gas-Fired Tumble Dryers. Energy 2021, 218, 119407. [CrossRef]

34. Wu, H.; Jouhara, H.; Tassou, S.A.; Karayiannis, T.G. Modelling of Energy Flows in Potato Crisp Frying Processes. Appl. Energy 2012, 89, 81-88. [CrossRef]

35. Aneke, M.; Agnew, B.; Underwood, C.; Menkiti, M. Thermodynamic Analysis of Alternative Refrigeration Cycles Driven from Waste Heat in a Food Processing Application. Int. J. Refrig. 2012, 35, 1349-1358. [CrossRef]

36. Bellocchi, S.; Guizzi, G.L.; Manno, M.; Pentimalli, M.; Salvatori, M.; Zaccagnini, A. Adsorbent Materials for Low-Grade Waste Heat Recovery: Application to Industrial Pasta Drying Processes. Energy 2017, 140, 729-745. [CrossRef]

37. Atkins, M.J.; Walmsley, M.R.W.; Neale, J.R. Integrating Heat Recovery from Milk Powder Spray Dryer Exhausts in the Dairy Industry. Appl. Therm. Eng. 2011, 31, 2101-2106. [CrossRef]

38. Aneke, M.; Agnew, B.; Underwood, C.; Wu, H.; Masheiti, S. Power Generation from Waste Heat in a Food Processing Application. Appl. Therm. Eng. 2012, 36, 171-180. [CrossRef]

39. Sapali, S.N.; Pise, S.M.; Pise, A.T.; Ghewade, D.V. Investigations of Waste Heat Recovery from Bulk Milk Cooler. Case Stud. Therm. Eng. 2014, 4, 136-143. [CrossRef]

40. Pantaleo, A.M.; Fordham, J.; Oyewunmi, O.A.; De Palma, P.; Markides, C.N. Integrating Cogeneration and Intermittent WasteHeat Recovery in Food Processing: Microturbines vs. ORC Systems in the Coffee Roasting Industry. Appl. Energy 2018, 225, 782-796. [CrossRef]

41. Mumith, J.-A.; Makatsoris, C.; Karayiannis, T.G. Design of a Thermoacoustic Heat Engine for Low Temperature Waste Heat Recovery in Food Manufacturing: A Thermoacoustic Device for Heat Recovery. Appl. Therm. Eng. 2014, 65, 588-596. [CrossRef]

42. Amón, R.; Maulhardt, M.; Wong, T.; Kazama, D.; Simmons, C.W. Waste Heat and Water Recovery Opportunities in California Tomato Paste Processing. Appl. Therm. Eng. 2015, 78, 525-532. [CrossRef]

43. Dogbe, E.S.; Mandegari, M.; Görgens, J.F. Assessment of the Thermodynamic Performance Improvement of a Typical Sugar Mill through the Integration of Waste-Heat Recovery Technologies. Appl. Therm. Eng. 2019, 158, 113768. [CrossRef]

44. Ling-Chin, J.; Bao, H.; Ma, Z.; Taylor, W.; Paul Roskilly, A. State-of-the-Art Technologies on Low-Grade Heat Recovery and Utilization in Industry. In Energy Conversion-Current Technologies and Future Trends; Al-Bahadly, I.H., Ed.; IntechOpen: London, UK, 2019; ISBN 978-1-78984-904-2.

45. Thekdi, A.; Nimbalkar, S.U. Industrial Waste Heat Recovery-Potential Applications, Available Technologies and Crosscutting R\&D Opportunities; 2015; Report number: ORNL/TM-2014/622, 1185778. Available online: http:/ /www.osti.gov/servlets / purl/1185778/ (accessed on 8 October 2021).

46. Wilfert, G.L.; Huber, H.B.; Dodge, R.E.; Garrett-Price, B.A.; Fassbender, L.L.; Griffin, E.A.; Brown, D.R.; Moore, N.L. Characterization of Industrial Process Waste Heat and Input Heat Streams; 1984; Report number: PNL-4912, 6834862. Available online: http:/ / www.osti.gov/servlets/purl/6834862/ (accessed on 8 October 2021).

47. Singh, R. Energy in Food Processing; Elsevier Science Publishing Company Inc.: Amsterdam, The Netherlands, 1986.

48. Wang, L. Energy Efficiency and Management in Food Processing Facilities; CRC Press: Boca Raton, FL, USA, 2009; ISBN 978-1-42006338-7.

49. National Dairy Council of Canada Guide to Energy Efficiency Opportunities in the Dairy Processing Industry 1997. Available online: https:/ / p2infohouse.org/ref/19/18807.pdf (accessed on 8 October 2021).

50. Focus on Energy Dairy Processing Industry. Energy Best Practice Guidebook. 2006. Available online: https://focusonenergy. $\mathrm{com} /$ sites/default/files/dairyprocess_guidebook.pdf (accessed on 8 October 2021).

51. Woolley, E.; Luo, Y.; Simeone, A. Industrial Waste Heat Recovery: A Systematic Approach. Sustain. Energy Technol. Assess. 2018, 29, 50-59. [CrossRef] 
52. Glatzl, W.; Brunner, C.; Fluch, J. GREENFOODS-Energy Efficiency in the Food and Beverage Industry. ECEEE Summer Study Proceedings. 2015. Available online: https:/ /www.eceee.org/library/conference_proceedings/eceee_Summer_Studies/2015/2 -energy-efficiency-policies-8211-how-do-we-get-it-right/greenfoods-energy-efficiency-in-the-food-and-beverage-industry/ (accessed on 14 December 2021).

53. Brunner, C.; Kulterer, K.; Fluch, J.; Glatzl, W. Greenfoods Branch Concept for Enhancing Energy Efficiency in the Food and Drink Industry. ECEEE Industrial Summer Study Proceedings. 2014. Available online: https://www.eceee.org/ library/conference_proceedings/eceee_Industrial_Summer_Study/2014/2-sustainable-production-design-and-supply-chaininitiatives/greenfoods-branch-concept-for-enhancing-energy-efficiency-in-the-food-and-drink-industry/ (accessed on 14 December 2021).

54. CE-HEAT Project Decision Support System (DSS). Available online: https://www.waste-heat.eu/waste-heat-toolbox/investmentdecision-support/decision-support-system (accessed on 14 December 2021).

55. Legislative Decree 4 July 2014, n¹02. 2014. Available online: https://www.gazzettaufficiale.it/eli/id/2014/07/18/14G00113/sg (accessed on 28 October 2021).

56. Cervo, H.; Ferrasse, J.-H.; Descales, B.; Van Eetvelde, G. Blueprint: A Methodology Facilitating Data Exchanges to Enhance the Detection of Industrial Symbiosis Opportunities-Application to a Refinery. Chem. Eng. Sci. 2020, 211, 115254. [CrossRef]

57. Malinauskaite, J.; Jouhara, H.; Ahmad, L.; Milani, M.; Montorsi, L.; Venturelli, M. Energy Efficiency in Industry: EU and National Policies in Italy and the UK. Energy 2019, 172, 255-269. [CrossRef]

58. Kluczek, A.; Olszewski, P. Energy Audits in Industrial Processes. J. Clean. Prod. 2017, 142, 3437-3453. [CrossRef]

59. Legislative Decree 14 July 2020, n. 73. 2020. Available online: https://www.gazzettaufficiale.it/eli/id/2020/07/14/20G00093/sg (accessed on 28 October 2021).

60. Ministero dello Sviluppo Economico. Clarifications Regarding Energy Audits in Fulfillment of Article 8 of the Legislative Decree n.102/2014. 2016. Available online: https:/ /www.mise.gov.it/images/stories/documenti/CHIARIMENTI-DIAGNOSI-14-nov2016.pdf (accessed on 28 October 2021).

61. European Commission. Joint Research Centre. Best Available Techniques (BAT) Reference Document for the Food, Drink and Milk Industries: Industrial Emissions Directive 2010/75/EU (Integrated Pollution Prevention and Control); Publications Office: Luxembourg, 2019; Available online: https:/ / data.europa.eu/doi/10.2760/243911 (accessed on 26 October 2021).

62. Ramírez, C.A.; Patel, M.; Blok, K. From Fluid Milk to Milk Powder: Energy Use and Energy Efficiency in the European Dairy Industry. Energy 2006, 31, 1984-2004. [CrossRef]

63. Modi, A.; Prajapat, R. Pasteurization Process Energy Optimization for a Milk Dairy Plant by Energy Audit Approach. Int. J. Sci. Technol. Res. 2014, 3, 181-188.

64. Bylund, G. Dairy Processing Handbook; Tetra Pak Processing Systems AB: Lund, Sweden, 1995; Available online: https:// dairyprocessinghandbook.tetrapak.com/ (accessed on 26 October 2021).

65. Carbon Trust. Referigeration: A Guide to Energy and Carbon Saving Opportunities. 2019. Available online: https://www. carbontrust.com/resources/refrigeration-guide (accessed on 28 October 2021).

66. Reis, C.; Nelson, E.; Armer, J.; Johnson, T.; Hirsch, A.; Doebber, I. Refrigeration Playbook. Heat Reclaim; Optimizing Heat Rejection and Refrigeration Heat Reclaim for Supermarket Energy Conservation; 2015; Report number: NREL/TP-5500-63786, 1215136. Available online: http://www.osti.gov/servlets/purl/1215136/ (accessed on 28 October 2021).

67. Istituto Nazionale di Statistica (ISTAT) ATECO (Classification of Economic Activity) 2007. Available online: https:/ /www.istat.it/ en/archivio/17959 (accessed on 28 October 2021).

68. Chaudhary, D.A.; Chaudhari, A.G. Performance Evaluation of a Plate Type (HTST) Milk Pasteurizer. Res. J. Anim. Husb. Dairy Sci. 2015, 6, 130-134. [CrossRef]

69. Hoffman, P. Simplified Balance of Line for Milk Powder Production. Processing Lines of Food Industry. 2003. Available online: https:/ / users.fs.cvut.cz/pavel.hoffman/ (accessed on 28 October 2021).

70. Department of the Environment, Transport and the Regions. Heat Recovery from Air Compressors Heat Recovery from Air Compressors. Good Practice Guide N${ }^{\circ}$ 238. 1998. Available online: https://www.thoriteinfo.co.uk/pdfs/good_practice_guide_ 238_heat_recovery_from_air_compressors.pdf (accessed on 27 October 2021).

71. Foell, W.K.; Lund, D.; Mitchell, J.W.; Ray, D.; Stevenson, R.; TenWolde, A. Low-Temperature Waste Heat Recovery in the Food and Paper Industries; 1980. Available online: https:/ /www.osti.gov/servlets/purl/6610811 (accessed on 2 November 2021).

72. Prabhakar, P.K.; Srivastav, P.P.; Murari, K. Energy Consumption during Manufacturing of Different Dairy Products in a Commercial Dairy Plant: A Case Study. Asia J. Dairy Food Res. 2015, 34, 98. [CrossRef]

73. SpiraxSarco. The Dairy Industry Steam and Condensate Systems. 2000. Available online: https://www.spiraxsarco.com/ (accessed on 27 October 2021).

74. Quijera, J.A.; Alriols, M.G.; Labidi, J. Integration of a Solar Thermal System in a Dairy Process. Renew. Energy 2011, 36, 1843-1853. [CrossRef]

75. Nagpal, H.; Spriet, J.; Murali, M.K.; McNabola, A. Heat Recovery from Wastewater-A Review of Available Resource. Water 2021, 13, 1274. [CrossRef] 
76. Brush, A.; Masanet, E.; Worrell, E. Energy Efficiency Improvement and Cost Saving Opportunities for the Dairy Processing Industry. An ENERGY STAR ${ }^{\circledR}$ Guide for Energy and Plant Managers. 2011. Available online: https://www.osti.gov/servlets/ purl/1171534 (accessed on 28 October 2021).

77. Atkins, M.J.; Walmsley, M.R.W.; Walmsley, T.; Fodor, Z.; Neale, J. Minimising Energy Use in Milk Powder Production Using Process Integration Techniques. Chem. Eng. Trans. 2012, 29, 1507-1512. [CrossRef] 